\title{
A Complementary Section for the Proposed Toarcian (Lower Jurassic) Global Stratotype: the Almonacid De La Cuba Section (Spain) ${ }^{1}$
}

\author{
M. J. Comas-Rengifo ${ }^{a}$, C. Arias ${ }^{a}$, J. J. Gómez ${ }^{b}$, A. Goy ${ }^{a}$, C. Herrero ${ }^{a}$, M. L. Osete ${ }^{c}$, and A. Palencia ${ }^{c}$ \\ "Departamento UEI de Paleontologia, UCM-CSIC, José Antonio Novais, 2, $28040 \mathrm{Madrid,} \mathrm{Spain}$ \\ e-mail:mjcomas@geo.ucm.es, cariasf@geo.ucm.es, angoy@geo.ucm.es, cherrero@geo.ucm.es \\ ${ }^{b}$ Departamento de Estratigrafia UEI de Correlaciones, UCM-CSIC, José Antonio Novais, 2, 28040 Madrid, Spain \\ e-mail:jgomez@geo.ucm.es \\ ${ }^{c}$ Departamento de Fisica de la Tierra I. Avenida Complutense s/n, Universidad Complutense, 28040 Madrid, Spain \\ e-mail:mlosete@fis.ucm.es, ali@fis.ucm.es
}

\begin{abstract}
We present the biostratigraphy (ammonites, brachiopods, foraminifers, and ostracodes), lithostratigraphy, sedimentology, sequence stratigraphy, magnetostratigraphy, and isotope stratigraphy of the Almonacid de la Cuba section located in the Iberian Range, central-eastern Spain. This section, which contains a continuous and expanded record of the Pliensbachian-Toarcian boundary (Early Jurassic), has been proposed as a complementary section for the Toarcian GSSP. An excellent ammonite-based biozonation has been obtained. Four ammonite assemblages characterized by the presence of Pleuroceras, Canavaria, Dactylioceras (Eodactylites), and Dactylioceras (Orthodactylites) have been distinguished. The base of the Toarcian is located at level CU35.2, based on the first occurrence of Dactylioceras. The occurrence of taxa from the NW European and the Mediterranean provinces is useful to improve the correlation between both provinces. Foraminiferal and ostracode assemblages are rich and diversified and no significant biostratigraphic events take place at the Pliensbachian-Toarcian boundary. The magnetostratigraphic data presented here are the most complete record of reversals of the earth magnetic field for the Pliensbachian-Toarcian boundary. A good record of the onset of the positive $\delta^{13} \mathrm{C}$ excursion reported in the Lower Toarcian of many European sections has been obtained. Average paleotemperatures measured at the latest Pliensbachian Spinatum Biochron of about $12.5^{\circ} \mathrm{C}$, recorded a marked increase of the seawater temperature which started during the Toarcian, reaching average temperatures of $16.7^{\circ} \mathrm{C}$ at the Tenuicostatum Biochron. The obtained ${ }^{87} \mathrm{Sr} /{ }^{86} \mathrm{Sr}$ values fully agree with the LOWESS calibration curve.
\end{abstract}

Key words: complementary Global Stratotype Section and Point, biostratigraphy, ammonites, brachiopods, foraminifera, ostracodes, magnetostratigraphy, geochemistry, Lower Jurassic, Spain.

\section{INTRODUCTION}

The Almonacid de la Cuba section located in the Iberian Range of central-eastern Spain (Fig. 1) shows a good representative record of the PliensbachianToarcian boundary under outstanding outcrop conditions (Fig. 2). The succession has been previously described by Sequeiros et al. (1978), Comas-Rengifo (1982), Goy et al. (1997, 2006), Comas-Rengifo et al. $(1999,2002)$ and proposed as a complementary section of the Toarcian Global Stratotype Section and Point (GSSP) (Elmi, 2006).

The current official candidate for designation as the GSSP for the base of the Toarcian stage is the Peniche section, located in western Portugal (Elmi et al., 1996;

\footnotetext{
${ }^{1}$ The article is published in the original.
}

Elmi, 2004, 2006; Hesselbo et al., 2007). However, no magnetostratigraphic scale has been constructed in the potential stratotype. Stable isotope curves in the Peniche section have been acquired from bulk carbonates (Duarte, 1998; Hesselbo et al., 2007) and $\delta^{13} \mathrm{C}$ and ${ }^{87} \mathrm{Sr} /{ }^{36} \mathrm{Sr}$ from belemnite carbonates (Hesselbo et al., 2007). However, no reliable $\delta^{18}$ curves have been reported and consequently a consistent record of paleotemperature variations based on $\delta^{18} 0$ proxies across the Pliensbachian-Toarcian transition has not been obtained.

Here we present the biostratigraphy (ammonites, brachiopods, foraminifers, and ostracodes), lithostratigraphy, sedimentology, sequence stratigraphy, magnetostratigraphy, and isotope stratigraphy of the Almonacid de la Cuba section, which contains a con- 


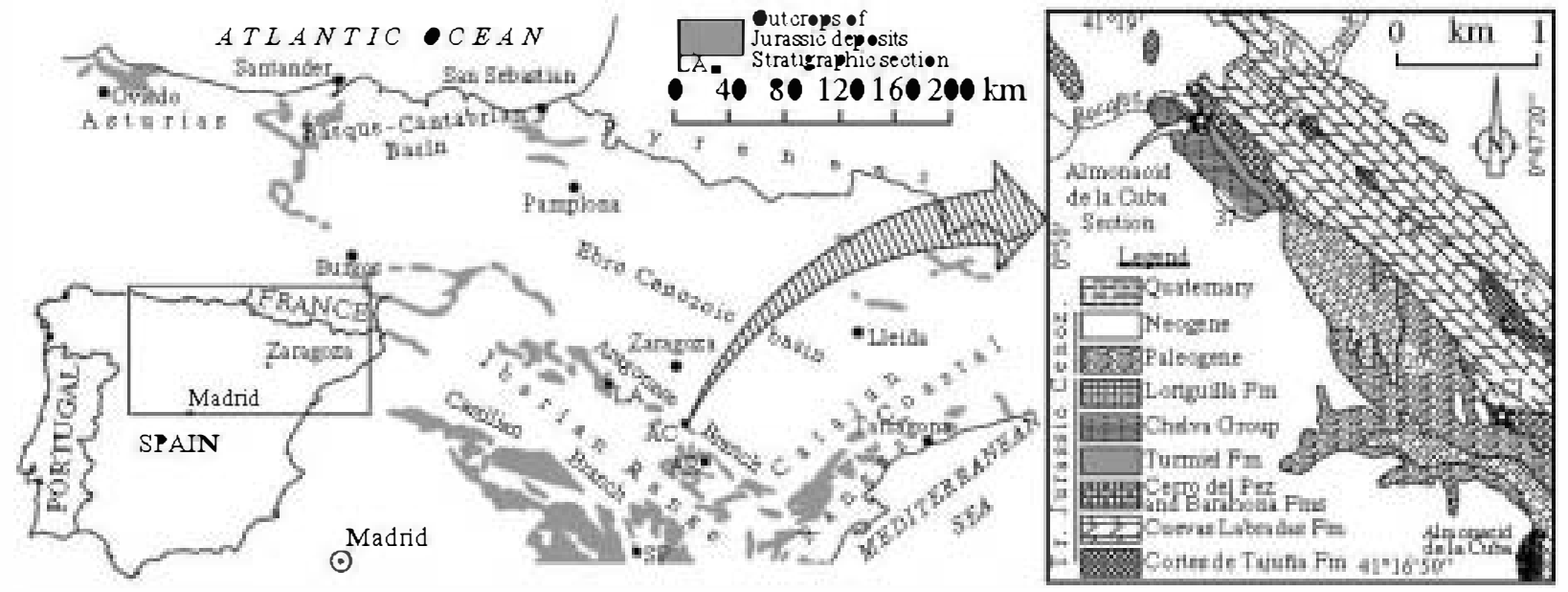

Fig. 1. Location maps ofthe Almonacid de la Cuba section: (a) Outcrops of the Jurassic deposits in central and northern Spain. Sections mentioned in the text: LA-La Almunia Section, AC-Almonacid de la Cuba Section, AR-Ariño Section, SPSierra Palomera Section. (b) Geologic map oft he Almonacidde la Cuba area (after Ruiz et al., 1986, modified) showing the position of the studied section. ACI - additional site sampled for the paleomagnetic fold test.

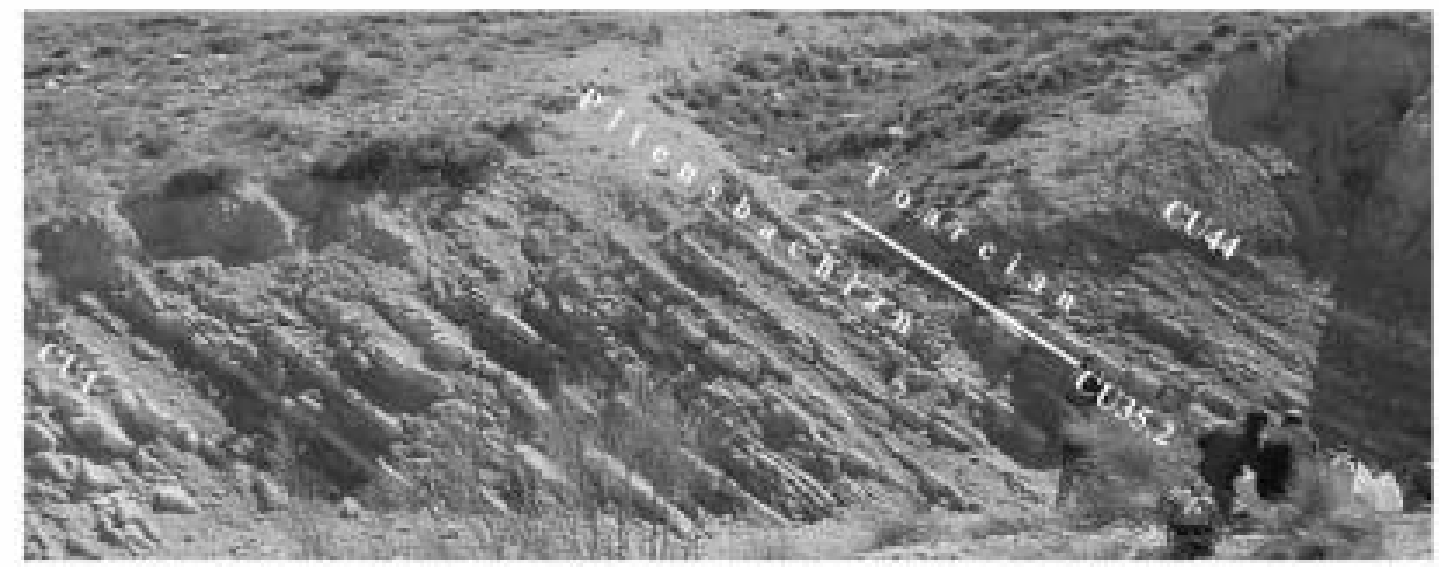

Fig. 2. View of the Almonacid de la Cuba section showing the position of the Pliensbachian-Toarcian boundary.

tinuous record of the Pliensbachian-Toarcian boundary. The results are discusse and compare with other European and American sections.

\section{MATERIAL AND METHODS}

The Almonacid de la Cuba section has been studied bed by bed, collected ammonites, were classified and belemnites prepare for isotopic studies. The natural gamma ray of the sediments was measured with a portable scintillation counter. Besides, 17 and 21 samples were collected to study foraminiferal and ostracode assemblages, respectively. Sample preparation involve initially soaking $300 \mathrm{~g}$ of dry rock in a solution of sodium hydroxide, hydrogen peroxide and water for 2-5 days. Once disaggregated, the samples were washed through $1-, 0.5-, 0.25-, 0.125-$ and $\mathbf{0} . \mathbf{0} 6 \mathbf{0}-\mathrm{mm}$ mesh sieves. All dried residues were scarmed on ablack picking tray under a stereoscopic microscope (Wild M-8 and Leica MZ-12). The hand-picked foraminifera and ostracodes of the $\mathbf{0 . 5 -}, \mathbf{0 . 2 5 -}$, and $\mathbf{0 . 1 2 5 - \mathrm { mm }}$ size fractions were used for taxonomic and diversity analysis.

A total of 40 belemnite rostra were collected and analyze to obtain the primary seawater stable isotope signal. For testing a possible burial diagenetic alteration, the rostra were studied on polished samples and thick sections under the petrographic and cathodoluminescence microscope. Only the potentially unaltere non-luminescent portions of the rostra were sampled using a microscope-mounted dental drill. Stable isotope analyses were prefonned in the Salamanca University (Spain) and in the Michigan University (USA) labs. In all samples isotope ratios are 
reported in per mil with respect to the standard Peedee belemnite (PDB). A total of 16 diagenetically screened belemnite calcite were analyzed for strontium isotope in the Laboratory of Geochronology and Isotopic Geochemistry of the Universidad Complutense of Madrid.

For the magnetostratigraphic study, a total of 57 samples were collected. To perform a paleomagnetic fold test, an additional site (18 samples from 4 stratigraphical levels) with a different structural tilt was studied (ACI site, Fig. 1). The structure sampled is not a single cylindrical fold, therefore an inclination test has also been performed. Magnetic analyses of specimens were carried out in the Paleomagnetic Laboratory of the ETH in Zürich and in the Paleomagnetic Laboratory of Madrid. Measurements of the natural remanent magnetization (NRM) and its response to stepwise thermal (TH) or alternating field (AF) demagnetization were measured using a $2 \mathrm{G}$ cryogenic magnetometer and a JR5 spinner magnetometers. Bulk susceptibility was measured at room temperature after each step of thermal treatment using a Kappabridge KLY-2, to detect the possible creation of new magnetic minerals during heating. In addition, isothermal remanent magnetization (IRM) experiments were carried out, consisting of stepwise acquisition of IRM up to $2 T$ with a pulse magnetizer (ASC Scientific IM-10-30), with at least 16 steps of IRM pulses. TH demagnetization of 3-axis IRMs (Lowrie, 1990) was performed on representative specimens. The orthogonal fields were $2 \mathrm{~T}, 0.4 \mathrm{~T}$ and $0.12 \mathrm{~T}$.

\section{LITHOSTRATIGRAPHY, SEDIMENTOLOGY AND SEQUENCE STRATIGRAPHY}

Two lithostratigraphical units can be recognized in the Almonacid de la Cuba section: the upper part of the Barahona Fm and the lower part of the Turmiel Fm. The deposits of the Barahona Fm are composed of bioclastic wackestone-packstone limestone with interbedded marls (Fig. 3). No sedimentary structures are visible in the carbonates of this unit most probably due to the high degree of bioturbation. Occasionally, reworking levels (RL in Fig. 3) evidenced by the presence of fossils containing signs of reworking, are interbedded in the sequence. The unit is topped by a thin ferruginous crust.

The Turmiel Fm is constituted by an alternation of marly lime mudstones and marls, except in its lowermost part, where the limestones are bioclastic lime wackestones, representing a transitional facies between the Barahona and the Turmiel Fms. The Pliensbachian-Toarcian boundary is located within the deposits of the Turmiel Fm (Fig. 3).

During the Early-Middle Jurassic, the Iberian Range was constituted by a system of carbonate platforms (the Iberian Platform system), affected by extensional tectonics that partly controlled the facies and thickness distribution and conditioned the pres- ence of mainly volcaniclastic deposits along the main fault zones (Gómez and Goy, 2005). The deposition of the Barahona Fm took place in an internal shallow, well-oxygenated carbonate platform, on which oysters (Gryphaea) were the predominant organisms, whereas remains of nektic organisms, such as ammonites and belemnites, are rare (Gómez, 1991; Gómez and Goy, 2005). Deposition of the Turmiel Fm occurred in a low-energy, normal salinity, open-marine external platform environment, where ammonites and belemnites were common. The transition between the shallow restricted and the open-marine platform environments was conditioned by the movement of syndepositional faults under extensional syndepositional tectonics, which occurred during the Late Pliensbachian-Early Toarcian. The hemipelagic facies of the Turmiel Fm in the Almonacid de la Cuba section were deposited in a downthrown block, where expanded sections with no significant discontinuities are recorded (Goy et al., 1997; Gómez and Goy, 2005). Under these conditions, a continuous ammonitebearing expanded section containing the Pliensbachian-Toarcian transition was formed.

Sequence stratigraphy has been based on the recognition of shallowing- and deepening-upward sequences in the field and is supported by the gammaray record (Fig. 3). The obtained facies cycles have been compared with the regional sequence stratigraphy model established by Gómez and Goy (2005) (Fig. 4). Upper Pliensbachian deposits are represented by the shallowing-upward sequences characterized by thickening-upward carbonates and thinning-upward marls, which are frequently topped by soft to firm grounds and occasionally by hard-grounds with ferruginous crusts. The Pliensbachian-Toarcian boundary is recorded within one of these shallowing-upward sequences, where no indications of significant stratigraphic gaps were found. The set of shallowing-upward sequences containing the Pliensbachian-Toarcian boundary, which corresponds to the LJ3-1 cycle for central and northern Spain (Fig. 4), is interrupted by an ephemeral transgressive interval that occurred during the early Tenuicostatum Biochron characterized by the thickening-upward marl sequences. However, the shallowing-upward sequences continue up to the top of Level 64, where a new transgressive episode corresponding to cycle LJ3-2, starts. The "Toarcian transgression" developed in few pulses, reaching the transgressive peak during the Middle Toarcian Bifrons Biochron, as it was observed in many other areas of Spain (Gómez and Goy, 2000, 2005). Radioactivity of the marls marking the individual facies cycles, clearly increases at the Turmiel Fm, with respect to the lithology of the Barahona Fm, reaching the maximum values in the Lower Toarcian. This fact could be interpreted in terms of an upward increase of ${ }^{40} \mathrm{~K}$, probably due to changes in the mineralogic composition of the source rock. 


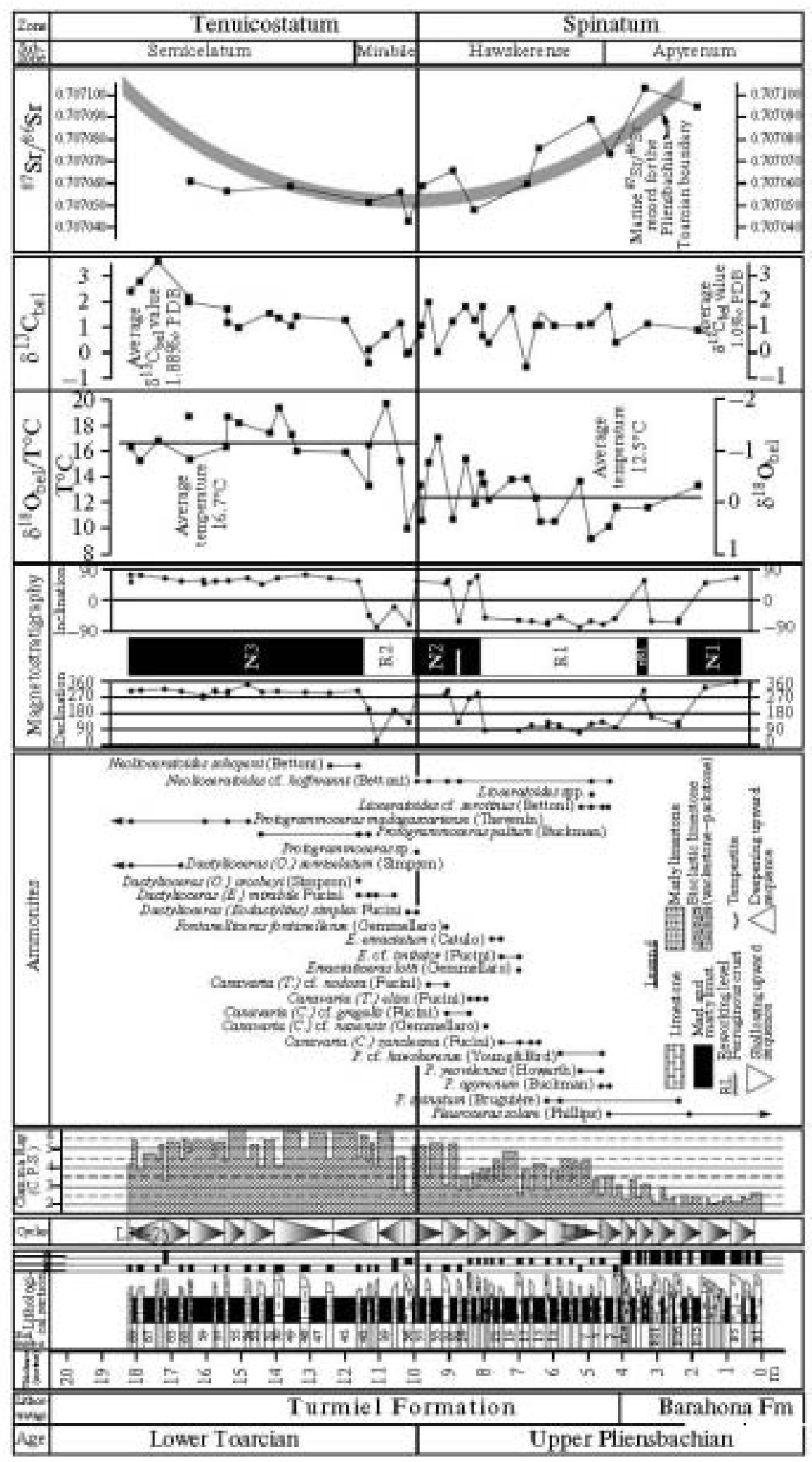


Fig. 3. Almonacidde la Cuba stratigraphic column showing the lithological succession, facies cycles, gamma-Iay curve, ammonite distribution, magnetostratigraphic chait, stable isotope, ${ }^{87} \mathrm{Sr} /{ }^{86} \mathrm{Sr}$ curves, andbiozonation. Seawaterpaleotemperatures have been calculated from the obtained $\delta^{18} \mathrm{O}_{\text {bel }}$ values and reflected at the upper part of the curve. Comparison of average paleotemperatures recorded during the ippermost Pliensbachian and the average paleotemperatures recorded at the Toarcian vary betureen 12.5 and $16.7^{\circ} \mathrm{C}$. This $\Delta \mathrm{T}$ marks the end of the Late Pliensbachian cooling event and the onset ofthe Early Toaician warming interval. The ${ }^{87} \mathrm{Sr} /{ }^{86} \mathrm{~S}$ r data are in good agreement with data shown in the LOWESS calibiation curve of McAIthur and Howarth (2004), shown in grey.
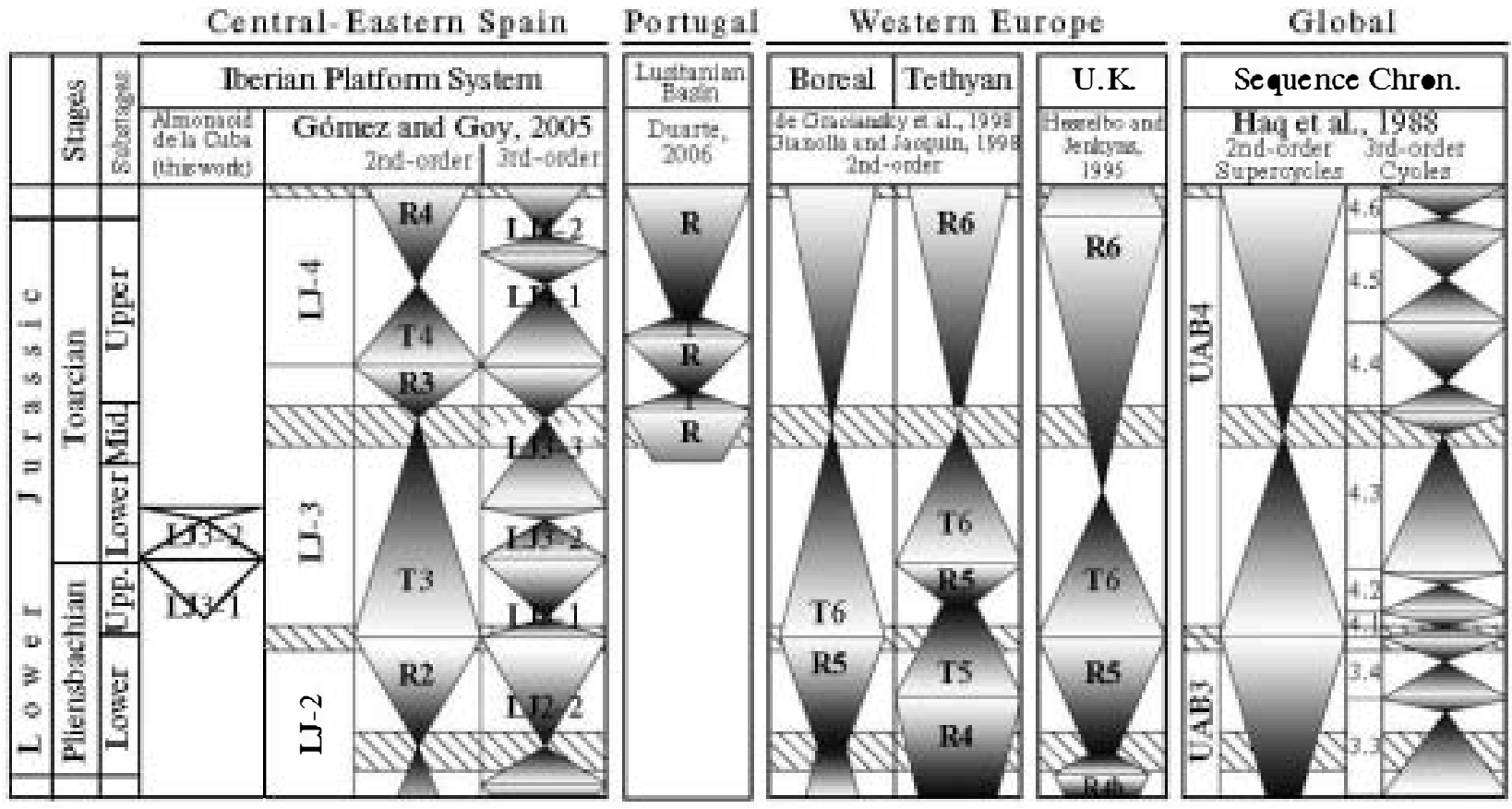

Fig. 4. Correlation chart oft he Pliensbachian-Toarcian facies cycles recognized in the Almonacid de la Cuba section (this work), general 2nd and 3rd order cycles of the Iberian Platform system (central-eastem Spain) (Gomez and Goy, 2005), the Lusitanian Basin of Portugal (Duarte, 2006), Western Europe (de Graciansky et al., 1998; Gianolla and Jacquin, 1998; Hesselbo and Jenkyns, 1995), and the Global sequences of Haq et al. (1988).

As correlation between the observed sedimentary facies cycles and the other published sequence stratigraphy charts can be seen in Fig. 4. One of the best correlation elements seems to be the transgressive event recorded at the base of Cycle LJ3-1, which can be observed in the Iberian Platfonn system as well as in the Boreal domain (de Graciansky et al., 1998; Gianolla and Jacquin, 1998), in the UK (Hesselbo and Jenkyns, 1995), and in the Global Sequence chart (Ha et al., 1988). Another good correlation event is the peak transgression of Cycle LJ 3-3, recorded in the Iberian Platfonn system and reported in the Boreal and Tethyan domains, as well as in the global chart of Haq et al. (1988).

\section{AMMONITE BIOSTRATIGRAPHY AND CORREIATION}

The Almonacid de la Cuba section contains an excellent record of the Pliensbachian-Toarcian boundary with no evidence of major sedimentation breaks. The ammonite assemblages are well repre- sented and lack signs of reworking except for those at levels BH.21 and BH.28. The studied time interval is characterize by the occurrence of Pleureceras, Cana-

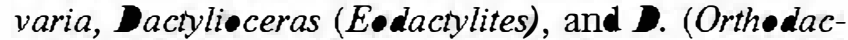
tylites). The latter subgenus has also been recorded in the Serpentinum Zone. A similar succession was recognizedin the Peniche section of Portugal (Mouterde, 1955; Elmi, 2004, 2006) and in northwestern Algeria (Elmi et al., 2006).

\section{The Spinatum Zøe (Upper Pliensbachian)}

The Spinatum Zone (at least $10.16 \mathrm{~m}$ thick) has been subdivided (Figs. 3 and 5) into the lower Apyrenum Subzone and the upper Hawskerense Subzone (Dean et al., 1961; Dommergues et al., 1997; Page, 2003; Goy et al., 2006; Meister et al., 2006).

The $4.98 \mathrm{~m}$ thick Apyrenum Subzone is characterjzed by the occurrence of Amaltheidae, particularly of the genus Pleureceras ( $P$. solare, $P$. spinaturn, $P$. apyrenum, and P. yevilense). Hildoceratidae (Harpocerati- 


\begin{tabular}{|c|c|c|c|c|c|c|c|c|c|c|}
\hline \multirow{3}{*}{ 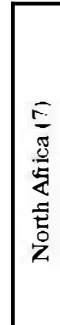 } & 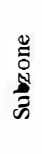 & \multicolumn{3}{|c|}{ 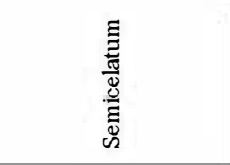 } & 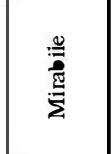 & \multicolumn{2}{|r|}{$\underline{8}$} & $\begin{array}{l}\frac{2}{0} \\
\frac{\pi}{0} \\
\text { b }\end{array}$ & 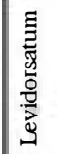 & 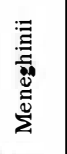 \\
\hline & & \multicolumn{3}{|c|}{ 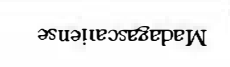 } & 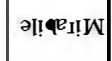 & \multirow{2}{*}{\multicolumn{2}{|c|}{ шидергетия }} & & \multirow{2}{*}{\multicolumn{2}{|c|}{ 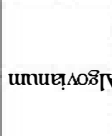 }} \\
\hline & $N$ & \multicolumn{4}{|c|}{ unydrow $\widehat{S I} \mathrm{O}_{\mathrm{d}}$} & & & & & \\
\hline \multirow{3}{*}{ 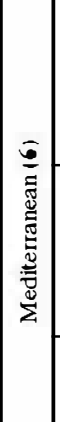 } & 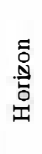 & 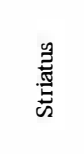 & \multicolumn{3}{|c|}{ 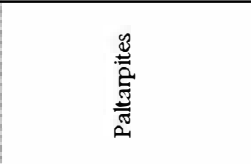 } & $\frac{g}{\bar{y}}$ & 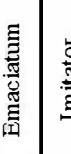 & 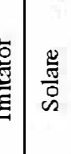 & 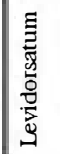 & 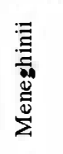 \\
\hline & 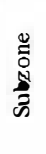 & & 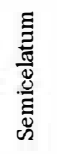 & & 总 & & $\frac{8}{\bar{y}}$ & 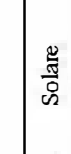 & 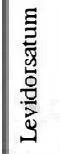 & 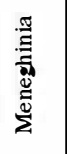 \\
\hline & ڤूँ & \multicolumn{4}{|c|}{ uny } & \multicolumn{3}{|c|}{ чипцергеши } & \multicolumn{2}{|c|}{ unutenos } \\
\hline \multirow{2}{*}{ 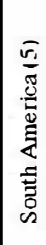 } & 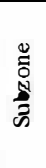 & \multicolumn{2}{|c|}{ 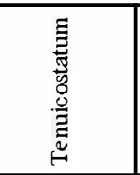 } & \multicolumn{2}{|c|}{ 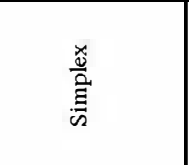 } & & 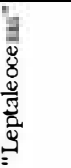 & & \multicolumn{2}{|l|}{ 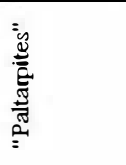 } \\
\hline & సัّ & \multicolumn{4}{|c|}{ unydrow $\delta_{[} \mathrm{O}_{\mathrm{d}}$} & \multicolumn{5}{|c|}{ 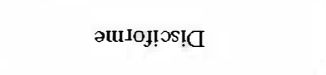 } \\
\hline \multirow{2}{*}{ 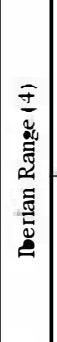 } & $\begin{array}{l}\text { : } \\
\text { : } \\
\text { 垔 }\end{array}$ & 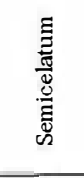 & 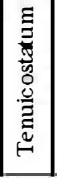 & 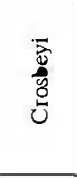 & 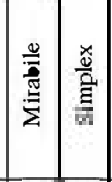 & $\frac{g}{\bar{y}}$ & 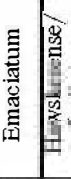 & 㤐 & \multicolumn{2}{|l|}{ 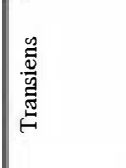 } \\
\hline & 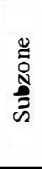 & \multicolumn{3}{|c|}{ 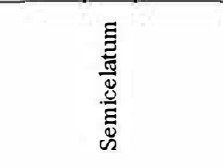 } & 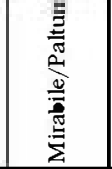 & \multicolumn{3}{|c|}{ 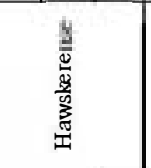 } & \multicolumn{2}{|l|}{ 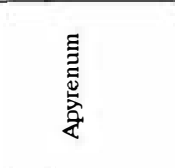 } \\
\hline \multirow{2}{*}{ 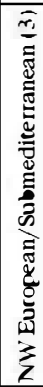 } & 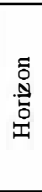 & 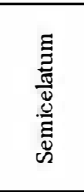 & 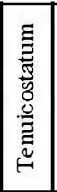 & 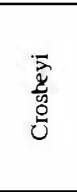 & 善 & 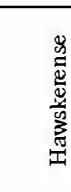 & 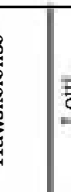 & 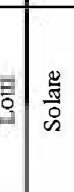 & 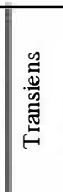 & 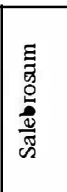 \\
\hline & 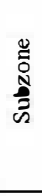 & \multicolumn{3}{|c|}{ 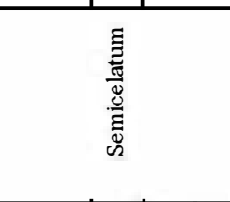 } & $\begin{array}{l}\text { 言 } \\
\text { 胥 }\end{array}$ & \multicolumn{2}{|c|}{ 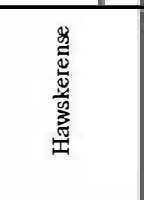 } & \multicolumn{3}{|c|}{ 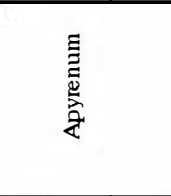 } \\
\hline \multirow{3}{*}{ 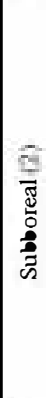 } & $\begin{array}{l}\text { 芯 } \\
\text { : } \\
\text { 品 }\end{array}$ & 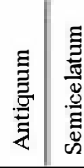 & 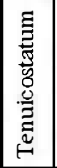 & 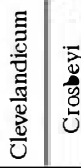 & 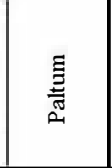 & 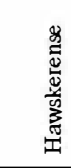 & 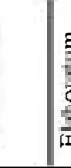 & 焉 & 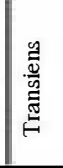 & 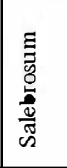 \\
\hline & 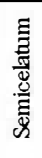 & 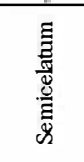 & 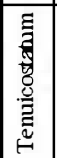 & 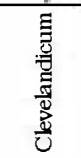 & 惑 & & 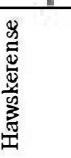 & & 音 & \\
\hline & ڤัँ & \multicolumn{4}{|c|}{ 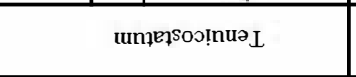 } & \multicolumn{5}{|c|}{ umpulds } \\
\hline 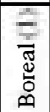 & $\Xi$ & \multicolumn{4}{|c|}{ unnḅ̣uv /unnbuldoId } & \multicolumn{5}{|c|}{ 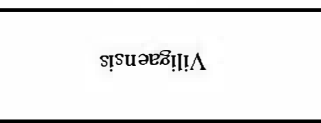 } \\
\hline
\end{tabular}

Fig. 5. Correlation chart of the chronobiostratigraphy of the Almonacid de la Cuba section [Iberian Range (4)] and Boreal, Subboreal, Submediterranean, Mediterranean, South American, and North African provinces selected scales. (1) Kalacheva (1988), Zakharov et al. (1997, 2006); (2) Dean et al. (1961), Howarth (1973, 1992), Page (2003); (3) Elmi et al. (1994, 1997), Dommergues et al. (1997), Page (2003); (4) Comas-Rengifo (1982), Goy and Martínez (1990), Goy et al. (2006); (5) Hillebrand (1987); (6) Braga et al. (1982), Braga (1983), Goy et al. (1988), Elmi et al. (1989, 1994, 1997), Dommergues et al. (1997), Macchioni (2002), Macchioni and Meister (2003, these authors in the Elisa Subzone found the succession: Naumachensis, Lorioli-Grecoi, Emaciatum, Serotinus), Meister et al. (2006); (7) Guex (1973), Elmi et al. (1974, 2006), Lachkar et al. (2007), Fauré et al. (2007).

nae) of the genera Lioceratoides ( $\boldsymbol{L}$. cf. serotinus) and Neolioceratoides ( $N$. cf. hoffmanni) also occur.

The Hawskerense Subzone, $5.8 \mathrm{~m}$ thick, is characterized by the presence of Amaltheids (Pleuroceras) and Arieticeratinae (Emaciaticeras, Canavaria, and locally Fontanelliceras). The Pleuroceras (P. spinatum, $P$. cf. yeovilense, and P. hawskerense) occur together with $\boldsymbol{L}$. cf. serotinus and $N$. cf. hoffmanni. The Pleuroceras species are replaced by the Canavaria species [C. (C.) zancleana, C. (C.) cf. gregaris, C. (T.) elisa, and $C$. $(\boldsymbol{T}$.) nodosa] and Emaciaticeras $(\boldsymbol{E}$. lotti, $\boldsymbol{E}$. cf. imitator, and E. emaciatum) between levels CU.16 and CU.34. Fontanelliceras fontanellense and N. hoffmanni are concurrent with Canavaria in the last levels of this subzone.

In brief, the assemblages of the lowerpart ofthe Hawskerense Subzone are dominated by the Amaltheids, whereas at some levels of the upper part the Arieticeratinae became the only constituent of the ammonite assemblage. The Harpoceratinae are less than $10 \%$ of the total, but are always present. The Spinatum Zone is characterized by the succession of Pleuroceras (P. transiens $-P$. solare $-P$. hawskerense), which are also used as zonal markers in NW Europe (Howarth, 1958, 1978, 1992; Comas-Rengifo, 1982; Dommergues et al., 1997; Page, 2003; Goy et al., 2006; Meister et al., 2006; Fauré et al., 2007; Lachkar et al., 2007). However, the assemblages of the upper part of the Spinatum Zone at Almonacid de la Cuba can also be compared with the ammonite zonation proposed for southern Europe, in which the use of the Emaciatum Zone subdivided into the Solare and the Elisa subzones is preferred (Braga et al., 1982, 1984; Braga, 1983; Macchioni, 2002; Meister et al., 2006). The beds containing $P$. hawskerense are correlated with the Hawskerense Subzone of the NW European province (Dommergues et al., 1997; Page, 2003; Meister et al., 2006). Levels with Emaciaticeras and Canavaria can be correlated with the Elisa Subzone of the Emaciatum Zone described by Braga et al. (1982) and Braga (1983) in the Betic Cordillera (southern Spain) and were also documented in the Mediterranean area by 
Macchioni and Cecca (2002), Macchioni and Meister (2003), Page (2003), and Meister et al. (2006).

\section{The Tenuicostatum Zone (Lower Toarcian)}

The Lower Toarcian Tenuicostatum Zone has been defined by the first appearance datum of the genus Dactylioceras used here for definition of the base of the Toarcian. The assemblage is characterized by species of the subgenera Dactylioceras (Eodactylites) and Dactylioceras (Orthodactylites) that characterize the Mirabile and the Semicelatum subzones, respectively. The stratigraphic range of the Tenuicostatum Zone in the Iberian Range coincides with that of the Semicelatum/Polymorphum Zone in Portugal and the Polymorphum Zone in the Betic Cordillera and North Africa (Mouterde, 1967; Comas-Rengifo and Goy, 1978; Goy et al., 1988, 1997; Elmi et al., 1989, 1994, 1997; Elmi, 2004, 2006; Bécaud, 2006).

The $1.57 \mathrm{~m}$ thick Mirabile Subzone is characterized by species of the subgenus Dactylioceras (Eodactylites) such as $D$. (E.) simplex, which allows correlation with some North African and South American sections (Elmi et al., 1974, 2006; Hillebrandt and Schmidt-Effing, 1981), and D. (E.) mirabile. This species corresponds to the Simplex and Mirabile horizons proposed by Goy et al. (1988). In some levels Neolioceratoides (N. hoffmanni, N. schopeni) and Protogrammoceras (P. paltum) also co-occur.

The Semicelatum Subzone (10.37 m thick) is characterized by the presence of several species of the subgenus Dactylioceras (Orthodactylites). The presence of $D$. $(O$.) crosbeyi characterizes the Crosbeyi Horizon of Goy and Martínez (1990), which is equivalent to the Clevelandicum Subzone defined by Howarth (1973). The species $D$. (O.) ernsti and $D$. (O.) semicelatum characterize the Semicelatum Horizon (Goy and Martínez, 1990), which is equivalent to the Semicelatum Subzone (Howarth, 1973). The absence of $D$. (O.) tenuicostatum between the levels bearing $D$. crosbeyi and the levels containing $D$. semicelatum does not permit the identification of the Tenuicostatum Horizon, which was reliably recognized in the nearby sections (Goy and Martínez, 1990). However, these assemblages also include Protogrammoceras, i.e. P. paltum and P. madagascariense.

Consequently, the assemblages of the Tenuicostatum Zone are dominated by Dactylioceratidae, whereas the Harpoceratinae members are less than 30\%. Other groups, such as Bouleiceratinae documented in the adjacent areas, have not been identified in the Almonacid de la Cuba section. Higher in the succession Cleviceras exaratum and Hildaites murleyi, which are generally used for characterization of the Serpentinum Zone, co-occur. In the younger levels of the same area, Harpoceras (H. serpentinum and other species) appear.

\section{BRACHIOPOD RECORD}

\section{AND COMPARISON WITH OTHER BASINS}

Brachiopod fauna shows a very high abundance throughout the Pliensbachian-Toarcian boundary in the Almonacid de la Cuba section (Fig. 6), where the majority of the species characteristic of the carbonate sediments corresponding to the Spinatum and Tenuicostatum zones of the Iberian Range (ComasRengifo, 1982, and references herein; Goy et al., 1997), have been recorded.

Within the Spinatum Zone the spiriferinids (S. munsteri, L. alpina, L. rostrata, and L. nicklesi), rhynchonellids (Q. attenuata and $G$. cantabrica), terebratulids (L. subpunctata, L. edwarsi, and L. arcta), and zeillerids ( $Z$. quadrifida, $Z$. indentata, and $A$. resupinata) have been recorded.

No relevant changes have been observed in the brachiopod assemblages during the Pliensbachian-Toarcian boundary (Goy et al., 1997). Some species mainly recognized in the SpinatumZone have also been identified in the Tenuicostatum Zone (L. alpina, Q. attenuata, G. cantabrica, L. subpunctata, $Z$. quadrifida, and A. resupinata) together with the other species ( $L$. falloti, L. arcta, and $Z$. culeiformis), which first occurrences take place within the characteristic marly sediments of the Hawskerense Subzone. All these species are associated with $A$. iberica in other sections near Almonacid de la Cuba.

The latter species (L.falloti, L. arcta, Z. culeiformis, and $A$. iberica) belong to different genera that were previously recorded in the Western Tethys. It is worth noting that due to their endemic character these species have also been recognized in the central sector of the Iberian Range up to the end of the Tenuicostatum Zone. These taxa abruptly disappeared in consequence of the mass extinction event that occurred near the Tenuicostatum-Serpentinum zonal boundary (García Joral and Goy, 2000; Gahr, 2002; Goy et al., 2006).

The extinction event is followe by a short interval without brachiopod record and the subsequent colonization of the basin by abundant and polymorphic assemblages of Soaresirh ynchia bouchardi (Davidson) during the Elegantulum Subzone. Immediately after these events numerous species of rhynchonellids and terebratulids typical for the "Spanish Bioprovince of Brachiopods" (García Joral and Goy, 1984), as Homoeorhynchia batalleri (Dubar), H. meridionalis (Deslongchamps), Choffatirhynchia vasconcellosi (Choffat), Lobothyris? hispanica (Dubar), Telothyris jauberti (Deslongchamps), etc., are recorded in the Almonacid de la Cuba section and in all the basins from $\mathrm{N}$ and $\mathrm{E}$ Spain, together with some other species as Pseudogibbirhynchia jurensis (Quenstedt), which has a wider distribution in the NW European Province (Goy et al., 1997; García Joral and Goy, 2000; 


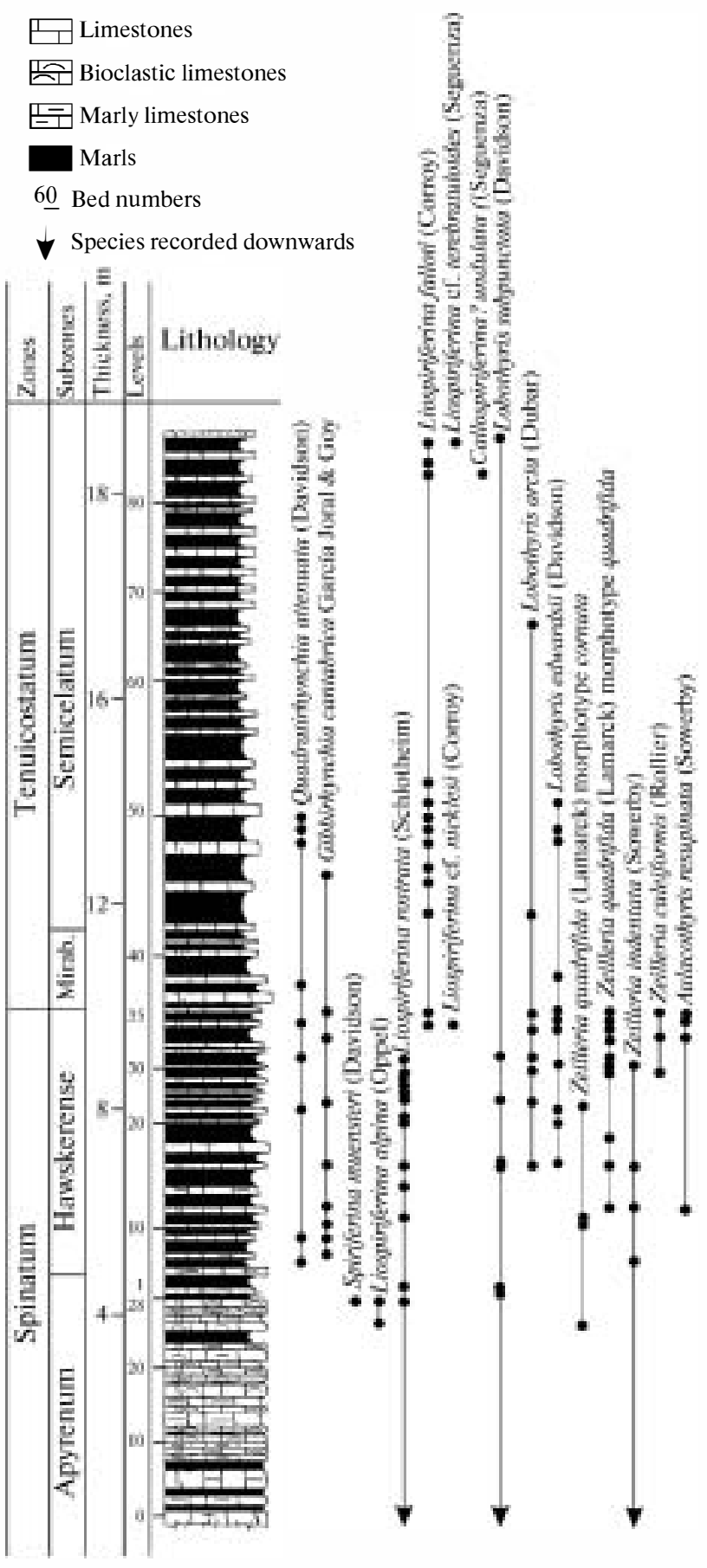

Fig. 6. Brachiopod range chart in the Spinatum and Tenuicostatum zones in the Almonacid de la Cuba section.

Alméras and Fauré, 2000; Gahr, 2002). However, the spiriferinids became definitely extinct after the mass extinction event (Comas-Rengifo et al., 2006).

\section{AND COMPARISON WITH OTHER BASINS}

The Spinatum and Tenuicostatum zones at the Almonacid de la Cuba section show very rich and well diversified foraminiferal assemblages (Herrero, 2006). They can be classified as "Nodosariid and Nodosariid-mixed assemblages" (type A.1 of Gordon (1970)) and are dominated by the suborder Lagenina, family Vaginulinidae. The suborders Textulariina, Miliolina, Spirillinina, and Robertinina are also present but in very low numbers. The most abundant genus is Lenticulina and the most diverse is Nodosaria (Fig. 7).

The stepwise extinction of an important number of typical long-ranging Lower Jurassic species involves the Tenuicostatum Zone. The taxa I. sulcata and $P$. pulchra show their last occurrences in the Mirabile Subzone; A. matutinus, A. speciosus, I. intumescens, and $P$. inaequistriata disappear in the middle part of the Semicelatum Subzone, and P. terquemi, M. prima, $M$. spinata, and $S$. sublaevis have their last occurrences in the upper part of the Semicelatum Subzone. On the contrary, $P$. tenera survives into the Serpentinum Zone. In other sections of the Iberian Range the last appearances of these species are also largely found at different levels of the Tenuicostatum Zone, although some taxa disappear early in the Spinatum Zone while a few persist into the Serpentinum Zone. In other European, North African, American, and Asian basins (see Herrero, 2008 and references herein) the last appearances of these long-ranging Lower Jurassic taxa occur at different levels within the Margaritatus and Spinatum zones, but mainly in the Tenuicostatum Zone. However, several species such as $P$. tenera and $P$. terquemi have survived, only to disappear in the Serpentinum Zone and the Middle Toarcian, respectively (Herrero, 2008).

The first appearance of some short-ranging species characteristic of the Spanish Lower Toarcian took place in the Spinatum (E. palomerensis) and Tenuicostatum ( $P$. obonensis and $S$. aragonensis) zones; their disappearance is recorded in the Semicelatum Subzone. In other sections of the Iberian Range, the Pyrenees, France and Morocco, P. obonensis has its last occurrence in the Serpentinum Zone (see Herrero, 2008). Two well-known Toarcian species ( $N$. liassica and $F$. jurensis) have their first appearances in the Tenuicostatum Zone. In other European and North African basins, $N$. liassica also appears in the Tenuicostatum Zone, in the Serpentinum Zone, or even in the Middle and Upper Toarcian (see Herrero, 2008 and references herein). The first record of $F$. jurensis in the Iberian Range as well as in all other European, North African and Asian basins, occurs in the Tenuicostatum Zone, Serpentinum Zone, Bifrons

Fig. 7. Foraminiferal relative abundance range chart in the Spinatum and Tenuicostatum zones of the Almonacid de la Cuba section. 


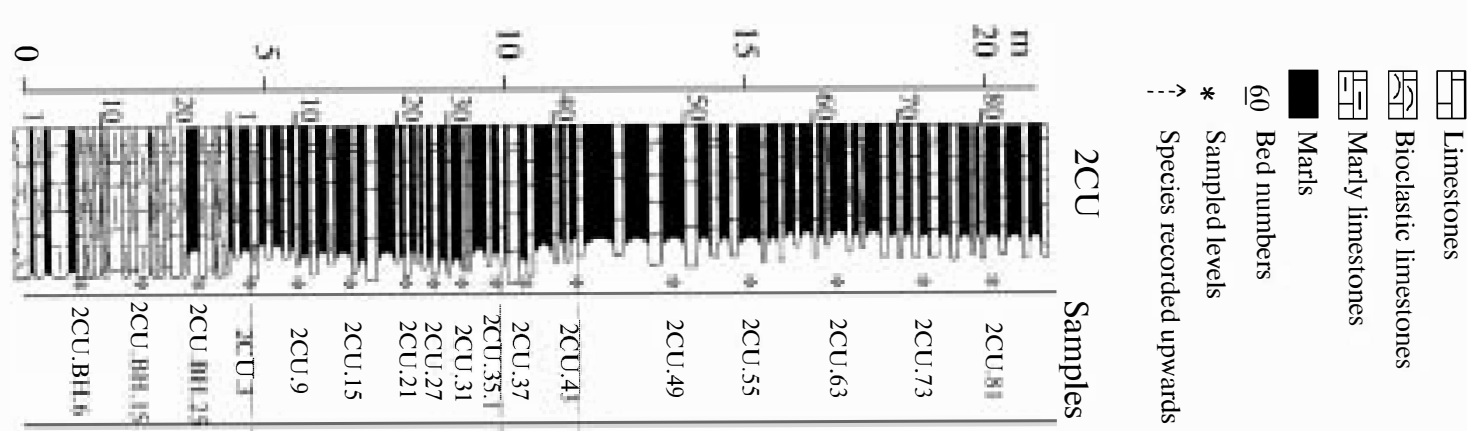

Codosaria $\mathrm{sp}$
- Reophax $\mathrm{sp}$

二-二二ב-二-1 -

二-二二Z-

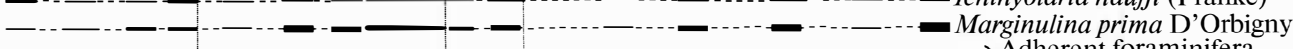

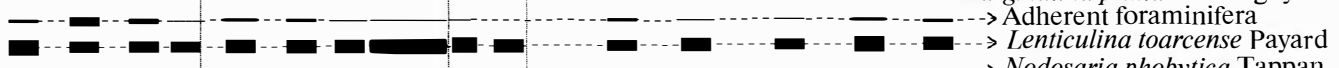

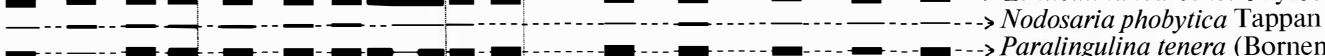

-

_- Planularia pulchra (Terquem)

______ Vaginulinopsis exarata (Terquem)

_-

二

_-___ _ _ _ - Nodosaria simplex (Terquem)

二- Alanularia protracta (Bornemann)

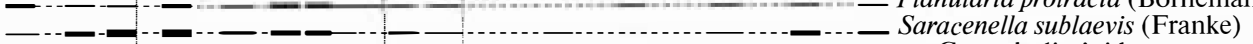

-

-

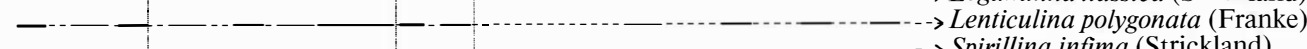

- Nodosaria sp. 1

- Vaginulinopsis sp.

_

_-

$\longrightarrow-\frac{1}{\text { Nodosaria sp. } 2}$

- Ophthalmidium sp.

_ Prodentalina matutina (D’Orbigny)

-

_

$[-\ldots$ Prodentalina subsiliqua (Franke)

-.- $\rightarrow$ Pseudonodosaria vulgata (Bornemann)

- _ _ _ - Nodosaria quinquelatera Franke

- Nodosaria apheilocula Tappan

- Nodosaria frentzeni Herrero

__ _ _ Astacolus speciosus (Terquem)

- Trochammina $\mathrm{sp}$. Nodosaria perlata Frentzen

- Ammobaculites vetustus (Terquem \& sexcota Terquem

- Prodentalina $\mathrm{sp}$.

- Tristix liasina (Berthelin)

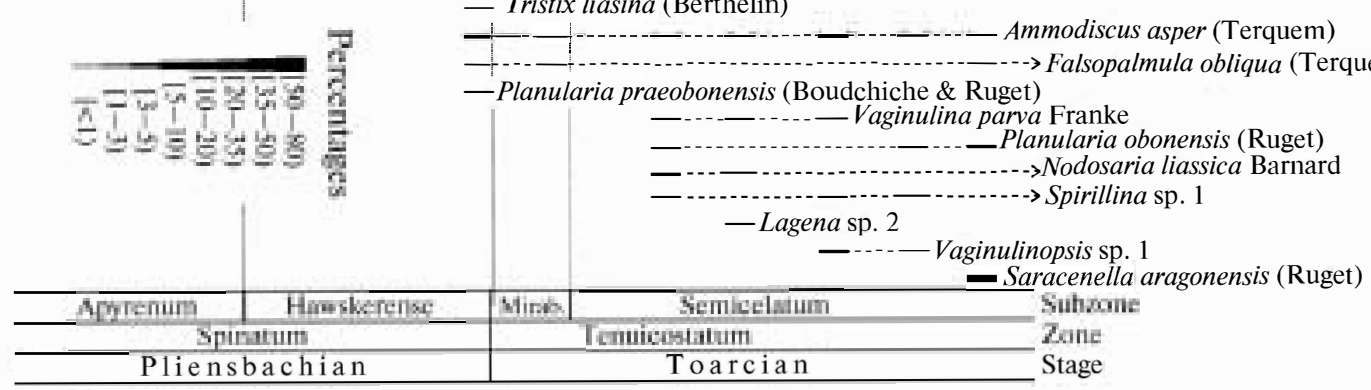




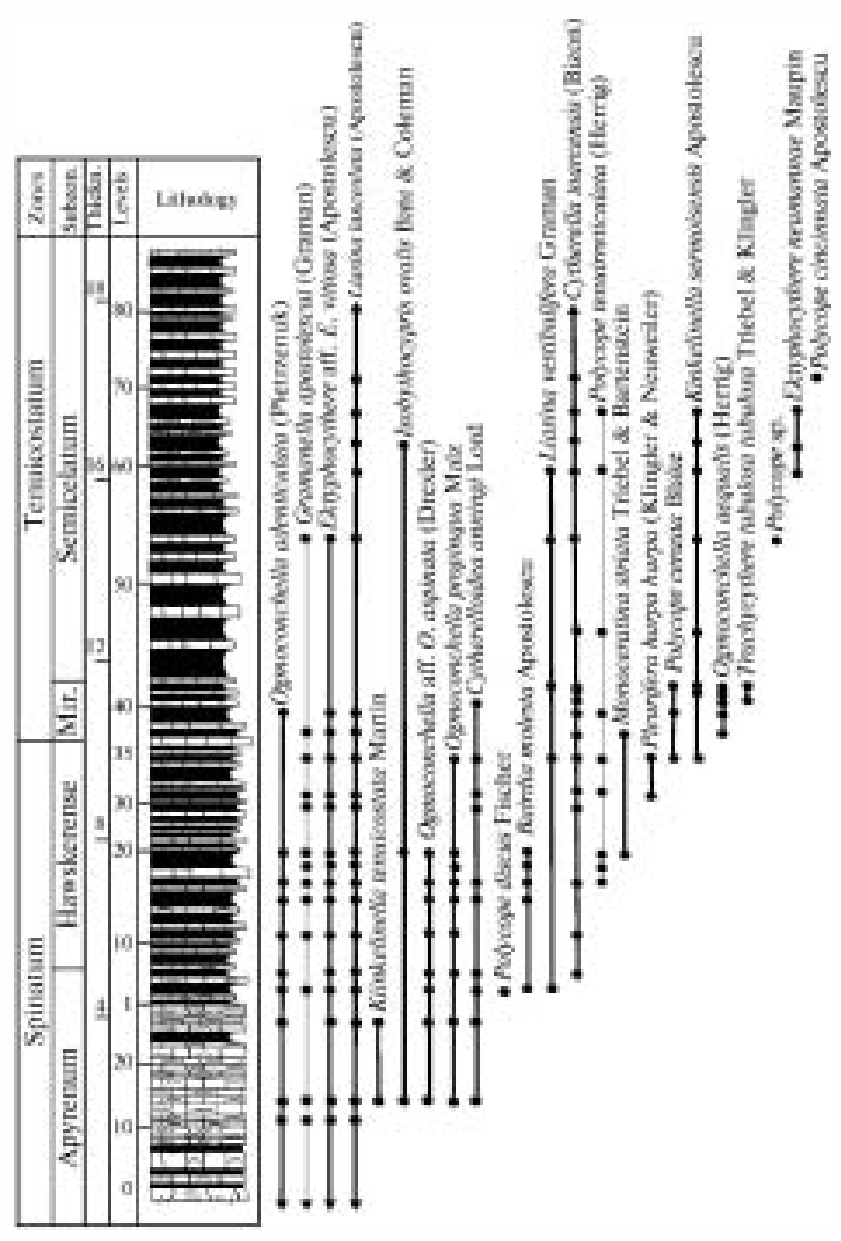

Fig. 8. Ostracode range chart in the Spinatum and Tenuicostatum zones of the Almonacid de la Cuba section.

Zone, Variabilis Zone, Thouarsense Zone, or even in the Pseudoradiosa Zone (see Herrero, 2008 and references herein).

\section{OSTRACODE RECORD AND COMPARISON WITH OTHER BASINS}

In the Almonacid Section the major faunal turnover in the ostracodes took place around the MirabileSemicelatum subzones transition at the generic and specific level (Arias, 2009). Eleven Upper Pliensbachian ostracode species crossed the PliensbachianToarcian boundary, and, therefore, the ostracode faunal turnover took place at the beginning of the Tenuicostatum Zone, Semicelatum Subzone, with the replacement of the typical Pliensbachian ostracode assemblages dominated by Healdiidae by a new association dominated by the Kinkelinella, Ektyphocythere, Cytherella, Isobythocypris, Polycope, Monoceratina, and Trachycythere species. All species reported in the Upper Pliensbachian, except for $C$. toarcensis (only recorded in the Falciferum Zone of the Paris Basin and Great Britain and in the Upper Toarcian and Aalenian of Ger- many, Switzerland, and Portugal) and $O$. aequalis (first found at the beginning of the Toarcian), are commonly recorded in the rest of Europe and North Africa from the same interval (Arias, 2000, 2009, and references herein). Across the Pliensbachian-Toarcian boundary $O$. adenticulata, C. anningi, $P$. harpa harpa, M. striata, and $P$. cerasia disappear. The Tenuicostatum Zone ostracode assemblage is as a whole similar to that from the uppermost Pliensbachian. Notable additions include the incoming of $K$. sermoisensis, E. neumannae, and $P$. cincinnata in the Tenuicostatum Zone, Semicelatum Subzone. The most abrupt and dramatic turnover in ostracodes is coincident with the MirabileSemicelatum subzones transition (CU43/47) (Fig. 8), where all healdioid species disappear and the representation of $G$. apostolescui and E. aff. E. vitiosa decreases. Above this level (CU47) the ostracode assemblages are dominated by $K$. sermoisensis, $C$. toarcensis, and L. lanceolata.

Based on the distribution and first and last occurrences of ostracode taxa, two zones were proposed for the Lower Jurassic of the Iberian Range (Arias, 2000): $O$. aff. $O$. aspinata and $O$. adenticulata and $K$. sermoisensis Ostracoda zones, and one subzone: L. lanceolata and K. tenuicostata Ostracoda Subzone. Exton and Gradstein (1984) and Riegraf (1985) defined their respective ostracode zones $(O$. cf. $O$. ambo Zone and $O$. ambo-O. impressa Zone) considering the first appearance of the cited species (Arias, 2000). Since these species are unknown until now in the Iberian Range, a direct correlation between the two ostracode zones is impossible. The O. adenticulata-N. (N.) simplex Zone was established by Michelsen (1975) as the uppermost zone of the Lower Jurassic ostracode zonation for the Danish Embayment, and its definition was based on the occurrence of $O$. adenticulata, which was considered an excellent marker species for the Upper Pliensbachian. The K. sermoisensis-E. intrepida ostracode Zone of Bate and Coleman of England and the Bairdiacypris sp. ostracode Zone described by Exton and Gradstein (1984) from the Grand Banks (Canada) and Zambujal (Portugal), could be correlated with the $K$. sermoisensis ostracode Zone of the Iberian Range (Arias, 2000, 2009). This zone may be partially correlated with the O. convexa Zone of Boomer (1992) from Ilminster (England) following the common occurrence of $K$. sermoisensis and $L$. lanceolata (Arias, 2000). In the Arctic realm (North Sea, West Siberia, Canadian Arctic and East Siberia, and northern Alaska provinces) there is one ostracode zone, the C. (C.) mandelstami Ostracoda Zone, the species not identified in the Iberian Range (Nikitenko, 2008; Arias, 2009). As the stratigraphic ranges of many of the species used are not concordant among different European areas, the correlation among the different zones is problematical and only can be resolved by comparison with the ammonite biostratigraphic scale. 
(a)

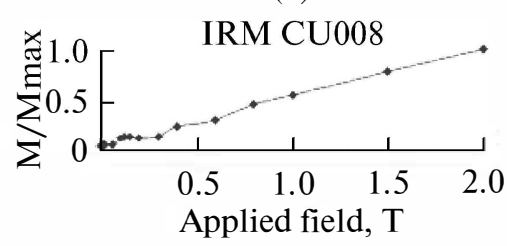

(b)

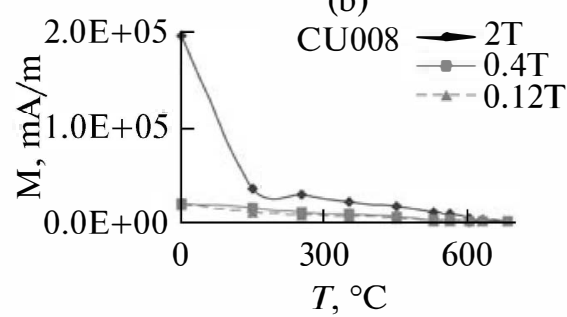

(c)

th/tc up/W

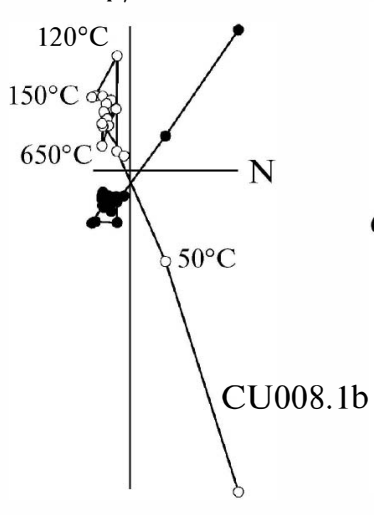

(d)

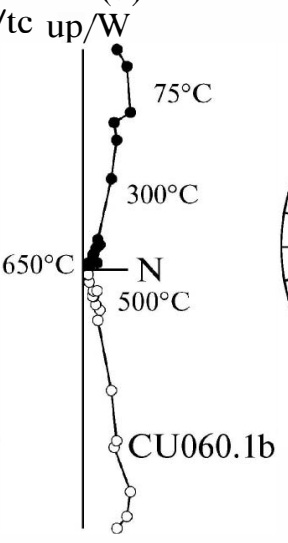

(e)

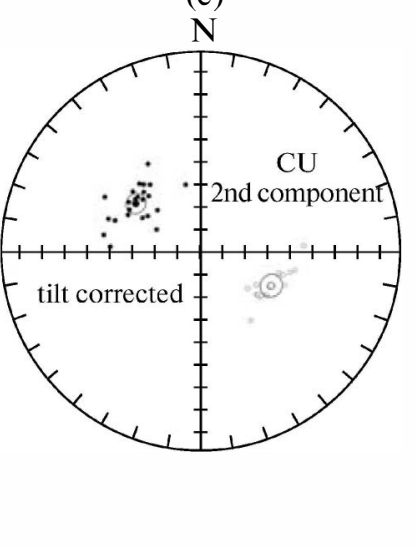

Fig. 9. IRM acquisition curve (a) and thermal demagnetization (b) of three orthogonal IRM components of a representative specimen; (c, d) orthogonal vector plots during thermal demagnetization of two typical samples of reversed (c) and normal (d) polarity; (e) equal area projection of the ChRM directions (2C: second component) at CU with tilt correction. In black dots (normal polarities), white dots (reversed polarities), and mean values with the $\alpha_{95}$ confidence angle.

\section{MAGNETOSTRATIGRAPHY}

\section{Paleomagnetic Results}

Natural Remanent Magnetization (NRM) intensity ranged from $5 \times 10^{-3}$ to $6 \times 10^{-5} \mathrm{~A} / \mathrm{m}$. Isothermal Remanent Magnetization (IRM) acquisition experiments indicate the presence of high coercitivity minerals, since saturation is not reached at $2 \mathrm{~T}$. In addition to this common feature, some samples showed the presence of low coercitivity minerals as well. Thermal demagnetization of three IRM orthogonal components corroborates that high coercitivity minerals carry most of the IRM in two phases: one with maximum unblocking temperature around $150^{\circ} \mathrm{C}$ indicating the presence of goethite and other with maximum unblocking temperature around $700^{\circ} \mathrm{C}$ indicating the presence of hematite (Figs. 9a, 9b). In addition to these high coercitivity minerals, some samples show the presence of a low coercitivity phase with maximum unblocking temperatures of $575-600^{\circ} \mathrm{C}$ indicating the presence of magnetite.

A pilot study revealed that alternating field demagnetization process was no effective in isolating the magnetic components because of the presence of high coercitivity minerals. In contrast, thermal demagnetization permitted to isolate two magnetic components (Figs. 9c, 9d). (1) A low unblocking temperature component carrying the $60-80 \%$ of the initial NRM intensity was isolated between room temperature and $150-200^{\circ} \mathrm{C}$ (goethite). This component exhibited the actual geomagnetic field direction (before tilt correction). In some cases it was observed at up to $350-$ $450^{\circ} \mathrm{C}$. The fold test (table) corroborates that this component has a secondary origin. (2) A high unblocking temperature component was isolated from $200-450^{\circ} \mathrm{C}$ up to $675-700^{\circ} \mathrm{C}$. This component exhibited very low intensities. It was necessary to perform a careful analysis and many heating steps after $4500^{\circ} \mathrm{C}$ to be able to isolate it. At CU site this component exhibited both normal and reversed polarities, while in the ACI site only reversed polarities were observed. This component was considered the Characteristic Remanent Magnetization (ChRM) of the site. The ChRM could be isolated in $75 \%$ of studied samples (49 samples at $\mathrm{CU}$ and 7 samples at $\mathrm{ACI})$.

The reversal test (McFadden and McElhinny, 1990) was performed at CU (transitional directions were excluded). The ChRM passed the test at the 95 and $99 \%$ significance level (table, Fig. 9e). Reversal test is of " $\mathrm{B}$ " type $\left(5^{\circ}<\gamma_{\mathrm{c}}<10^{\circ}\right)$, at both 95 and $99 \%$ confidence level. This means that the ChRM component was correctly isolated.

Fold test results are listed in table. The statistical parameters used to estimate the significance of fold test were determined by using the McFadden and Jones (1981) method. The best grouping of ChRM directions is observed after tilt correction, but the fold test is not statistically significant at the $95 \%$ level of confidence. This is probably due to structural problems (more than one phase of tilting around different horizontal axis) since inclinations tend to converge after bedding correction, but not declinations. Therefore apparent block rotations cannot be excluded. A fold test using only inclination values has been performed. Inclination means were calculated by using the McFadden and Reid (1982) method. The inclination fold test was positive at the $99 \%$ confidence level. This guarantees that the ChRM is primary in origin and acquired in Early Jurassic times.

\section{Magnetic Polarity Column}

A magnetic polarity column for the Pliensbachian-Toarcian boundary has been constructed on 
Paleomagnetic directions of the $1 \mathrm{C}$ and $2 \mathrm{C}$ components at CU and ACI. Reversal and fold test parameters

\begin{tabular}{|c|c|c|c|c|c|c|c|c|c|c|c|c|c|c|c|}
\hline Site/1C Component & $\mathbf{n}$ & Dec & Inc & $\mathbf{k}$ & $\boldsymbol{u}_{95}$ & $\mathbf{R}_{\text {sum }}$ & & Dec & Inc & $\mathbf{k}$ & $a_{95}$ & $\mathbf{R}_{\text {sum }}$ & \multicolumn{3}{|c|}{ Fold-test } \\
\hline $\mathrm{CU} / 1 \mathrm{C}$ & 9 & 360.0 & 62.5 & 49.6 & 7.4 & 8.8 & & 285.7 & 57.0 & 49.6 & 7.4 & 8.8 & & & \\
\hline ACI/1C & 12 & 358.2 & 62.1 & 154.0 & 3.5 & 11.9 & $\mathbf{f}$ & 230.9 & 46.3 & 154.0 & 3.5 & 11.9 & $\mathbf{f}^{*}$ & $\mathbf{F}_{95 \%}$ & $F_{99 \%}$ \\
\hline $\mathrm{ACI}+\mathrm{CU} / 1 \mathrm{C}$ & 21 & 359.0 & 62.3 & 85.7 & 3.5 & 20.8 & 0.004 & 250.0 & 53.9 & 17.3 & 7.9 & 19.8 & 3.881 & 0.17 & 0.27 \\
\hline Site/2C Component & $\mathbf{n}$ & Dec & Inc & $\mathbf{k}$ & $u_{95}$ & $\mathbf{R}_{\text {sum }}$ & & Dec & Inc & $\mathbf{k}$ & $a_{95}$ & $\mathbf{R}_{\text {sum }}$ & $\begin{array}{l}\text { Rever } \\
\text { Fold- } \\
\text { Inclin } \\
\text { fold te }\end{array}$ & $\begin{array}{l}\text { sal test } \\
\text { test } \\
\text { lationo } \\
\text { est }\end{array}$ & nly \\
\hline CU/2C NORMAL (N) & 23 & 0.9 & 51.5 & 55.1 & 4.1 & 22.6 & & 304.0 & 55.5 & 55.1 & 4.1 & 22.6 & $\gamma_{0}$ & $\gamma_{c 95 \%}$ & $\gamma_{c 99 \%}$ \\
\hline CU/2C Reversed (R) & 15 & 184.2 & -57.2 & 70.7 & 4.6 & 14.8 & & 114.8 & -59.0 & 70.7 & 4.6 & 14.8 & & & \\
\hline CU/2C Mean $(N+R)$ & 38 & 2.1 & 53.8 & 57.2 & 3.1 & 37.4 & & 300.7 & 56.9 & 57.2 & 3.1 & 37.4 & 6.1 & 6.2 & 7.7 \\
\hline ACI 2C Reversed & 7 & 180.7 & 4.7 & 40.8 & 9.6 & 6.9 & f & 162.3 & -51.0 & 40.8 & 9.6 & 6.9 & $\mathbf{f}^{*}$ & $\mathrm{~F}_{95 \%}$ & $\mathrm{~F}_{99 \%}$ \\
\hline $\mathrm{ACI}+\mathrm{CU} / 2 \mathrm{C}(\mathrm{N})$ & 45 & 1.9 & 45.7 & 12.1 & 6.4 & 41.6 & 3.74 & 307.5 & 57.0 & 33.0 & 3.8 & 43.7 & 0.85 & 0.07 & 0.11 \\
\hline $\begin{array}{l}\mathrm{ACI}+\mathrm{CU} / 2 \mathrm{C} \\
\text { inclination }\end{array}$ & 45 & - & 45.2 & 6.13 & 9.7 & - & 9.11 & - & 55.0 & 72.55 & 2.0 & - & 0.091 & 0.072 & 0.113 \\
\hline
\end{tabular}

Note: (n) Number of samples; (Dec) declination; (Inc) inclination; (k, $\left.\alpha_{95}\right)$ statistical parameters (Fisher, 1953); (N) normal polarity; (R) reversed polarity; $\left(\gamma_{0}, \gamma_{c}(95 \%)\right.$, $\left.\gamma_{c}(995)\right)$ reversal test parameters (McFadden and McElhimy, 1990); (f, f*, F95\%, and $\left.F_{99 \%}\right)$ fold test parameters (McFadden and Jones, 1981).

the basis of the polarities of the ChRM (Fig. 3). Three normal and two reversed polarity magnetozones have been identified, named N1-3 and R1-2. Within the R1 magnetozone a smaller magneto-subzone has been identified and labelled nR1. Polarity identified by only one sample is marked by a discontinuous bar. At the bottom of the column the Nl magnetozone is observed within the Pliensbachian Apyrenum Subzone. $\mathrm{R} 1$ is a long magnetozone extending up to the upper Hawskerense Subzone. Within R1 a small magneto-subzone $\mathrm{nRl}$ is observed, which is located near the top of the Barahona Fm. The end of the Hawskerense Subzone is characterized by a normal polarity (N2 magnetozone). R2 nearly coincides with the boundaries of the Mirabile Subzone and contains the lower boundary of the Toarcian, which is close to the N2-R2 magnetozones boundary. N3 is a long magnetozone which characterizes the Tenuicostatum Zone, starting in the upper part of the Mirabile Subzone and extending up to the top of the section (Semicelatum Subzone).

\section{Magnetostratigraphic Correlations}

The magnetostratigraphy from the Almonacid de la Cuba section has been compared with other coeval European/Tethyan and American magnetostratigraphic columns (Fig. 10).

The Breggia Gorge section (Southern Alps) has been traditionally considered as the best documented section for the Early Jurassic magnetostratigraphy (Horner and Heller, 1983), but the Tenuicostatum Zone is only poorly represented. The Magnetic Polarity Time Scale (MPTS) proposed by $9 g 8$ (1995, 2004) was mostly based on the Italian Breggia section; consequently, the Pliensbachian-Toarcian boundary is not well defined. A new Magnetic Polarity Time Scale for the Toarcian has been recently proposed by Osete et al. (2007), based on the study of two well dated sections from the Iberian Range (Sierra Palomera and Ariño) and on the correlation with previous European paleomagnetic studies. But this MPTS embraces only the Toarcian. The Neuquén magnetostratigraphic sections (South America, Iglesia-Llanos and Riccardi, 2000) present some problems, the major among them are: (1) the sampling interval (too high to solve in detail the sequence of reversals of the Earth's magnetic field) and (2) the correlation with the European biostratigraphic zones. This latter problem has been recently discussed by Riccardi (2008).

The column from the Paris Basin (Moncornet) studied by Moreau et al. (2002) shows important sedimentary discontinuities at the Pliensbachian-Toarcian boundary. The Moncornet section provides a good description of the reversals of the Earth's magnetic field for the Early Pliensbachian, other than for the Upper. For this reason this section has not been included in Fig. 10. The magnetostratigraphic sections from Thouars and Airvault (Galbrun et al., 1988) have not been included in the correlation because the Tenuicostatum Zone is absent.

In summary, there are only few previous magnetostratigraphic studies spanning the Lower Toarcian and the Pliensbachian-Toarcian boundary. In Fig. 10a magnetostratigraphic correlation is proposed between the Almonacid de la Cuba section and the best magnetostratigraphically studied European sections for this 
(a)

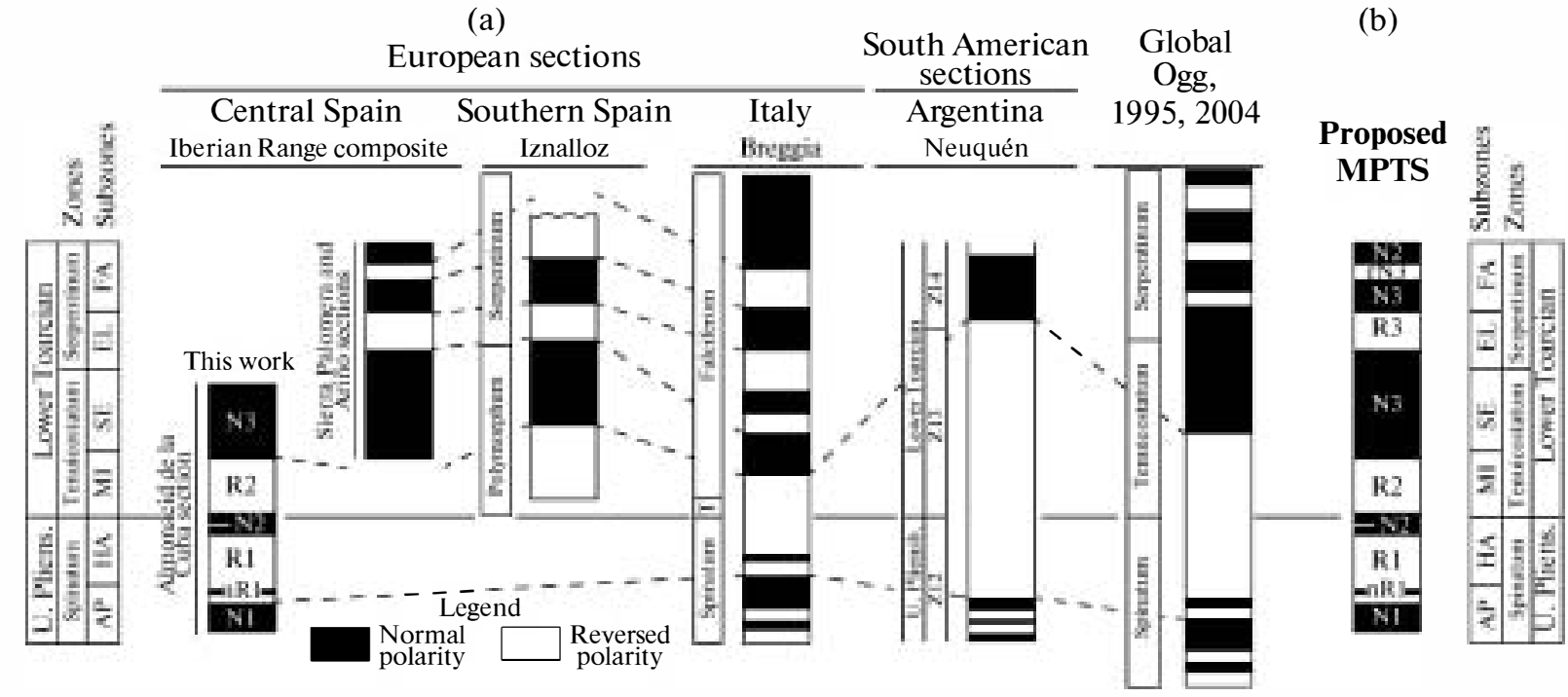

Fig. 10. (a) Magnetostratigraphic correlation between all Upper Pliensbachian-Lower Toarcian sections and the new magnetostratigraphic column proposed in this paper. AP-Apyrenum, HA-Hawskerense, MI-Mirabile, SE-Semicelatum, ELElegantulum, FA-Falciferum. (b) Comparison between the MPTS proposed by Ogg $(1995,2004)$ and the MPTS proposed in this work.

time interval, namely, Breggia (Horner and Heller, 1983), Iznalloz (Galbrun et al., 1990), and the Iberian Range composite section (Osete et al., 2007). In addition, the studied section has also been compared with the Neuquén composite section from Argentina (Iglesia-Llanos and Riccardi, 2000).

A good correlation is observed in the general pattern of reversals between the columns represented in Fig. 10, but some more detailed features recorded in the Almonacid de la Cuba section are missing in the other sections. From younger to older they are: (1) N3 is a clear magnetozone observed at the Iznalloz section (Betic Cordillera, southern Spain) by Galbrun et al. (1990) and also reported from the Sierra Palomera and Ariño sections (Iberian Range, central Spain) by Osete et al. (2007). This magnetozone seems to be also recorded in Breggia and Neuquén (but not accurately biostratigraphycally dated). (2) The R2 magnetozone (Mirabile Subzone) is also in agreement with the reversed polarity observed in the lower part of the Iznalloz section. It is also shown in Breggia and Neuquén columns. (3) The N2 magnetozone is only present in the Almonacid de la Cuba section. It is located at the end of the Hawskerense Subzone, close to the Pliensbachian-Toarcian boundary. (4) R1 is a clear magnetozone observed in the two other sections (Breggia and Neuquén). But R2 and R1 were recorded as a unique magnetozone in Breggia and Neuquén. The N2 magnetozone located between them has not been detected in the Alpine and American sections. The Lower Toarcian is only poorly represented in the Breggia section (the Tenuicostatum Zone is about $30 \mathrm{~cm}$ thick), and probably there is a gap at the Pliensbachian-Toarcian boundary, according to data pre- sented here. Afew number of samples studied from the Neuquén sections explains the low resolution of the South American column. Finally, a good correlation is observed between the lower part of the Almonacid de la Cuba and Breggia sections.

The Magnetic Polarity Time Scale (MPTS) proposed by Ogg $(1995,2004)$ was mostly based on the Italian Breggia section (Fig. 10) and, consequently, is consistent with the general pattern of our data, but the N2 magnetozone is absent and the age control of the Lower Toarcian reversals is poor. The new MPTS proposed by Osete et al. (2007) for the Toarcian is in agreement with the new data presented here, but it does not extend below the Toarcian. Therefore the magnetostratigraphic data presented here are the most complete record of reversals of the Earth's magnetic field for the Pliensbachian-Toarcian boundary.

The new MPTS, which includes the MPTS proposed by Osete et al. (2007) and the new data presented in this study, is also plotted in Fig. 10.

\section{ISOTOPE STRATIGRAPHY AND PALEOTEMPERATURES}

The presence of belemnites in virtually all the studied beds permitted the obtaining of excellent $\delta^{13} \mathrm{C}-\delta^{18} \mathrm{O}$ and ${ }^{87} \mathrm{Sr} /{ }^{86} \mathrm{Sr}$ curves based on diagenetically screened belemnite calcite(Figs. 3, 11, 12).

\section{Stable Isotope Record}

The $\delta^{13} \mathrm{C}_{\text {bel }}$ record shows values ranging from -0.52 to $3.59 \%$ PDB. These values tend to be quite uniform in the uppermost Pliensbachian, averaging 1\%o PDB, 


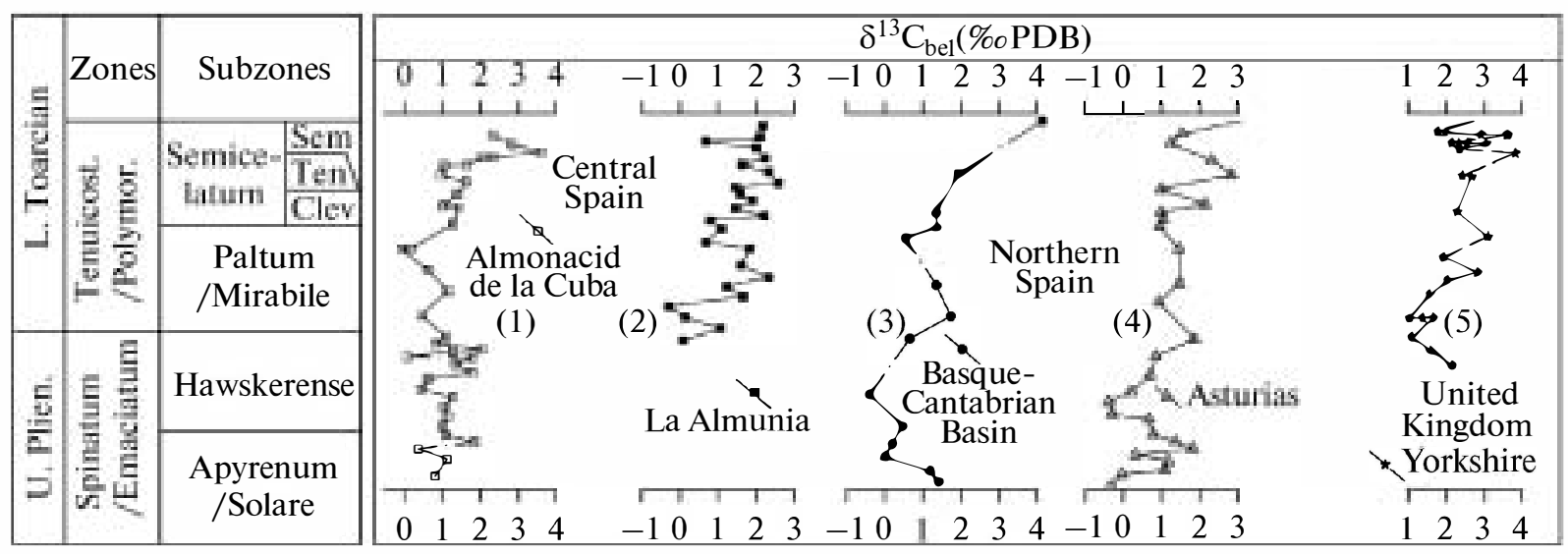

Fig. 11. Correlation chart of the $\delta^{13} \mathrm{C}_{\text {bel }}$ curves obtained in belemnite carbonates in Western Europe. Central Spain: (1) Almonacid de la Cuba section (this work), (2) La Almunia section (Gomez et al., 2008); northern Spain: (3) Basque-Cantabrian Basin (Rosales et al., 2001) (see Fig. 1 for location), (4) Asturias (Gómez et al., 2008) (see Fig. 1 for location); United Kingdom: (5) Yorkshire (McArthur et al., 2000).

but they tend to increase in the lowermost Early Toarcian, where average values of $1.88 \%$ PDB were reached. The increase in the $\delta^{13} \mathrm{C}_{\text {bel }}$ values marks the onset of a positive excursion which has been recorded in most European sections, whether it be in bulk rock or belemnite carbonates, in marine organic matter, and in wood (e.g., Jenkyns and Clayton, 1997; Schouten et al., 2000; McArthur et al., 2000; Hesselbo et al., 2007; Gómez et al., 2008).

Comparison of the obtained $\delta^{13} \mathrm{C}_{\mathrm{bel}}$ record with other curves received from belemnite calcite in sections located in central and northern Spain and in northwestern Europe (Yorkshire, UK), are shown in Fig. 11. In all sections the $\delta^{13} \mathrm{C}_{\text {bel }}$ values are ranging from slightly negative values (up to $-1 \%$ ) to $4 \%$ o PDB. No major excursions have been observed but it seems quite common that the negative $\delta^{13} C_{\text {bel }}$ values are preferentially recorded in the Upper Pliensbachian Hawskerense Subzone and in the lowermost Toarcian Paltum/Mirabile Subzone. The highest values are always recorded at the upper Tenuicostatum Zone (Semicelatum Subzone), marking the onset of the positive $\delta^{13} \mathrm{C}_{\mathrm{bel}}$ excursion mentioned above.

Most of the authors are in agreement regarding the interpretation of the Early Toarcian positive excursion as the response of water masses to excess and rapid burial of large amounts of organic carbon rich in ${ }^{12} \mathrm{C}$, that led to enrichment in ${ }^{13} \mathrm{C}$ of the sediments (Jenkyns and Clayton 1997; Schouten et al., 2000), or to removal from oceans of large amounts of isotopically light carbon as organic matter into black shales or methane hydrates, which leaves oceanic carbon isotopically heavy (McArthur et al., 2000).

In the $\delta^{18} \mathrm{O}_{\text {bel }}$ curve that shows values ranging from 0.73 to $-1.71 \%$ o PDB, the significant changes at the Pliensbachian-Toarcian transition are observed as well. During the Spinatum Biochron the $\delta^{18} \mathrm{O}_{\text {bel }}$ values averaged slightly negative values $(-0.29 \%$ PDB $)$, but around the stages transition, an excursion towards more negative values averaging $-1.3 \%$ PDB is recorded. This negative $\delta^{18} \mathrm{O}_{\text {bel }}$ shift has also been reported in many European sections such as Dotternhausen in Germany (Röhl et al., 2001; Schmid-Röhl et al., 2002), the Whitby and Yorkshire areas in the UK (Sælen et al., 1996; Jenkyns, 2003), and in northern Spain, in the Basque-Cantabrian Basin (Rosales et al., 2004) and in Asturias, as well as in other sections located in central Spain (Gómez et al., 2008).

\section{Seawater Temperatures}

The obtained $\delta^{18} \mathrm{O}_{\text {bel }}$ values were used as a proxy for calculation of paleotemperatures recorded in the belemnite rostra at the Pliensbachian-Toarcian transition. For this purpose the Anderson and Arthur (1983) equation

$$
T\left({ }^{\circ} \mathrm{C}\right)=16.0-4.14\left(\delta_{\mathrm{c}}-\delta_{\mathrm{w}}\right)+0.13\left(\delta_{\mathrm{c}}-\delta_{\mathrm{w}}\right)^{2}
$$

has been used, where $\delta_{\mathrm{c}}=\delta^{18} \mathrm{O}$ PDB composition of the sample and $\delta_{\mathrm{w}}=\delta^{18} \mathrm{O}$ SMOW composition of ambient seawater $(-1 \%$ o for a nonglacial ocean water). Normal values of $S=34.3 \%$ o for the marine salinity (Wright, 1987) were assumed.

The temperature variations during the Late Pliensbachian-Early Toarcian are shown in Figs. 3 and 12. In the latest Pliensbachian Spinatum Biochron the paleotemperatures were relatively low ranging from $9.2^{\circ} \mathrm{C}$ recorded around the Apyrenum-Hawskerense zonal boundary up to $17^{\circ} \mathrm{C}$ calculated in one sample located near the Pliensbachian-Toarcian boundary. The average paleotemperature of $12.5^{\circ} \mathrm{C}$ calculated for the Late Pliensbachian notably increased during the Early Toarcian, where average calculated temperatures were $16.7^{\circ} \mathrm{C}$, including peak values above $19.5^{\circ} \mathrm{C}$ reached during the Mirabile and Semicelatum biochrons. 


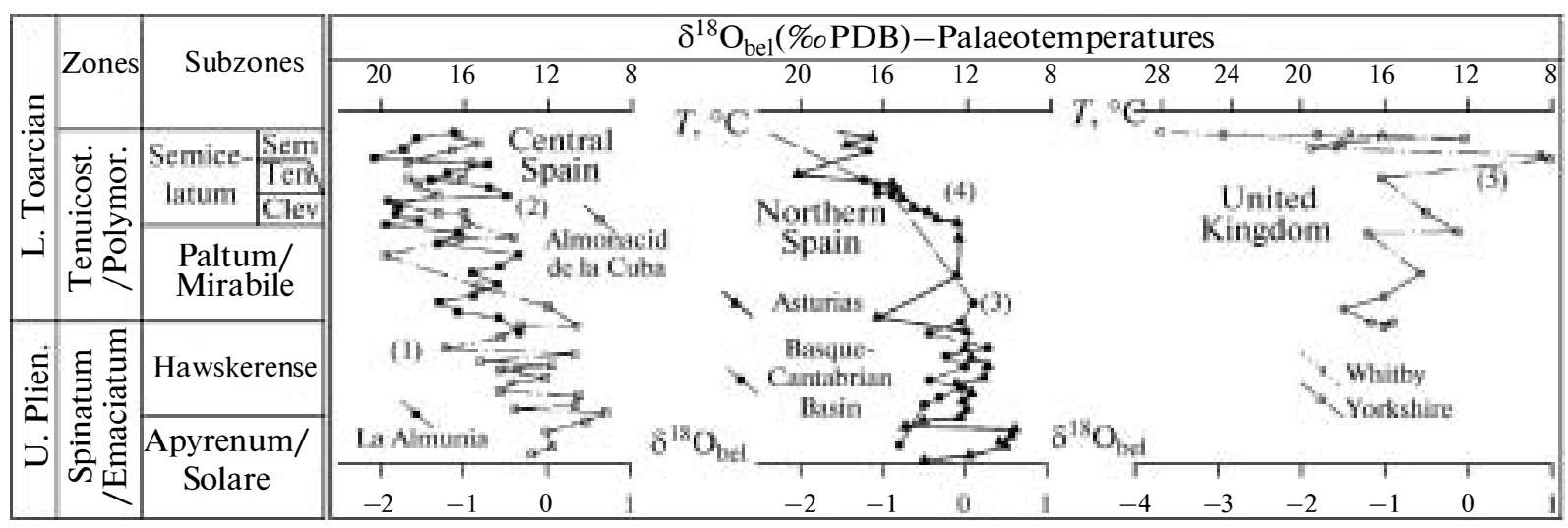

Fig. 12. Correlation chart of the $\delta^{18} \mathrm{O}_{\text {bel }}$ curves and calculated paleotemperatures in Western Europe. Central Spain: (1) Almonacid de la Cuba section (this work), (2) La Almunia section (Gómez et al., 2008); northern Spain: (3) Basque-Cantabrian Basin (Rosales et al., 2001) (see Fig. 1 for location), (4) Asturias (Gómez et al., 2008) (see Fig. 1 for location); United Kingdom: (5) Yorkshire (Jenkyns, 2003), Whitby (Sælen et al., 1996).

Average paleotemperatures measured in the latest Pliensbachian Spinatum Biochron of about $12.5^{\circ} \mathrm{C}$ are in good agreement with the average temperatures of $11.6^{\circ} \mathrm{C}$ calculated in Asturias (northern Spain, Gómez et al., 2008) and of $12^{\circ} \mathrm{C}$ in the Basque-Cantabrian Basin (also in northern Spain, Rosales et al., 2004) (Fig. 12). These temperatures can be considered low for a calculated central Spain paleolatitude of about $35^{\circ} \mathrm{N}$ during the Pliensbachian-Toarcian (Osete et al., 2000, 2007). Similar values of oceanic paleotemperatures recorded in the UK and Germany (Bailey et al., 2003) confirm that the latest Pliensbachian and the earliest Toarcian represent a relative cooling interval (Tremolada et al., 2005) also recorded in north Siberia and the Arctic region (Zakharov et al., 2006).

A marked increase of seawater temperature started during the earliest Toarcian. In the Tenuicostatum Biochron the average temperatures of $16.7^{\circ} \mathrm{C}$ in the Almonacid de la Cuba section, $15^{\circ} \mathrm{C}$ in the Asturias sections, and $16^{\circ} \mathrm{C}$ in the La Almunia section located in the Iberian Range near the studied section, were recorded (Gómez et al., 2008). This represents a $\Delta T$ between 4 and $5^{\circ} \mathrm{C}$ around the Pliensbachian-Toarcian transition. This paleotemperature rise is probably one of the main causes of the so-called upper Pliensbachian biotic crisis, and clearly marks the onset of the outstanding Early Toarcian warming interval, which starts around the Tenuicostatum-Serpentinum biochrons boundary in many European sections and extensively develops during the Early and Middle Toarcian (McArthur et al., 2000; Jenkyns, 2003; Rosales et al., 2004; Gómez et al., 2008), as well as in north Siberia and Arctic regions (Zakharov et al., 2006).

Correlation of the $\delta^{18} \mathrm{O}_{\text {bel }}$ and paleotemperature curves obtained in belemnite calcite samples from Almonacid de la Cuba and other sections of central and northern Spain and the United Kingdom (York- shire and Whitby), is shown in Fig. 12. All the correlated curves show a progressive decrease in the $\delta^{18} \mathrm{O}_{\text {bel }}$ values, toward more negative figures, from the Upper Pliensbachian Spinatum Zone to the Lower Toarcian Tenuicostatum Zone. This correlation suggests the progressive seawater warming that dramatically increases in the Lower Toarcian Serpentinum Zone (Gómez et al., 2008). The lower part of the Yorkshire curve tends to shift toward less negative and even positive values, but in the upper part of the Tenuicostatum Zone these values rapidly decrease toward more negative values, marking higher paleotemperatures than that calculated in the Spanish sections.

\section{${ }^{87} \mathrm{Sr} /{ }^{86} \mathrm{Sr}$ curve}

The plots of obtained ${ }^{87} \mathrm{Sr} /{ }^{86} \mathrm{Sr}$ values against the stratigraphic column are displayed in Fig. 3. The highest values in the studied interval $(0.707104)$ are recorded in the uppermost Pliensbachian Apyrenum Zone. These values gradually fall towards values lower than 0.707050 around the Pliensbachian-Toarcian boundary, shifting towards higher values in the Lower Toarcian, where values of 0.707062 are reached in the belemnite calcite sampled in the Semicelatum Subzone. This negative excursion has been recognized in the UK sections (McArthur et al., 2000), from which the reconstruction of the standard seawater ${ }^{87} \mathrm{Sr} /{ }^{86} \mathrm{Sr}$ curve of variations for the Early Jurassic has been obtained.

The ${ }^{87} \mathrm{Sr} /{ }^{86} \mathrm{Sr}$ values obtained in the Almonacid de la Cuba section fully agree with the previously published data (McArthur et al., 2000, 2001; McArthur and Howarth, 2004; Hesselbo et al., 2007). The Upper Pliensbachian ${ }^{87} \mathrm{Sr} /{ }^{86} \mathrm{Sr}$ values generally decrease during the Hawskerense Biochron reaching the first minimum value below 0.707050 in the late portion of this time interval, and slightly increase in the latest portion of this biochron. Minimum values are recorded at the 
base of the Toarcian, as predicted by the LOWESS calibration curves, and ${ }^{87} \mathrm{Sr} /{ }^{86} \mathrm{Sr}$ slowly increases along the Tenuicostatum Zone. These results strongly support the reliability of the available ${ }^{87} \mathrm{Sr} /{ }^{86} \mathrm{Sr}$ values and the good geochemical signal included in the belemnite calcite of this section.

\section{CONCLUSIONS}

Four ammonite assemblages characterized by the presence of Pleuroceras, Canavaria, Dactylioceras (Eodactylites), and Dactylioceras (Orthodactylites), have been distinguished. The base of the Toarcian is located at level CU35.2 based on the first occurrence of Dactylioceras.

The ammonite assemblages of the Tenuicostatum Zone mainly contain taxa characteristic of the NW European province, such as Protogrammoceras paltum and Dactylioceras $(O$.) with predominance of Dactylioceratidae over Harpoceratinae. However, taxa of the Mediterranean province, such as Neolioceratoides, Dactylioceras $(\boldsymbol{E}$.), and $\boldsymbol{P}$. madagascariense are only recognized at few levels. In the Mirabile Subzone D. (Eodactylites) co-occurs with P. paltum. The occurrence of taxa from both provinces in the Almonacid de la Cuba section is useful to improve the correlation between the NW European and the Mediterranean provinces.

Two paleobiogeographic features can be highlighted: (1) the occurrence of $D$. (E.) simplex allows correlation with the level $15 \mathrm{E}$ of the Peniche section, as well as with some North African and South American sections; (2) P. paltum is a good marker for correlation with the NW European and Mediterranean provinces. In the Ricla section (Iberian Range, Spain), Peniche section (Lusitanian Basin, Portugal), and the Mellala section (Traras Mountains, Algeria) this species, or a similar form, occurs at the base of the Mirabile Subzone. P. paltum is also common at the Mirabile Horizon in the Mediterranean area.

Related to brachiopods, a first assemblage constituted by typically Pliensbachian taxa ( $S$. muensteri, $L$. alpina, $L$. rostrata, $Q$. quadrata in proximal areas, L. subpunctata, $Z$. indentata, $Z$. quadrifida, and $A$. resupinata) and a second assemblage with similar species but of more endemic character ( $\boldsymbol{L}$. falloti, C. ? undulata, $Q$. attenuata, G. cantabrica, L. arcta, $Z$. culeiformis, and $A$. iberica in proximal areas), have been recorded. After a short time interval that coincides with the Tenuicostatum-Serpentinum zonal boundary, the mass extinction event characterized by a monospecific assemblage of $S$. bouchardi is recorded in this region.

Foraminiferal assemblages do not show significant biostratigraphic events at Pliensbachian-Toarcian boundary. Rather, the main biostratigraphic events took place along the Pliensbachian-Toarcian transition (Spinatum to Serpentinum Zones) with the extinction, replacement, and renewal of a significant number of species. On the basis of the number of extinct taxa per ammonite zone and subzone, the highest extinction rate appears within the Semicelatum Subzone of the Tenuicostatum Zone. The genera Marginulina and Saracenella and some species of Astacolus, Eoguttulina, Falsopalmula, Ichthyolaria, Nodosaria, Prodentalina, and Planularia are of the greatest biostratigraphic and chronostratigraphic interest.

The ostracode record shows that the major Early Jurassic ostracode faunal turnover event occurred not at the end of the Pliensbachian, but near the top of the Mirabile ammonite Subzone, Tenuicostatum Zone. The Upper Pliensbachian and Lower Toarcian (Mirabile Subzone) ostracode assemblages are dominated by healdioids and $\boldsymbol{G}$. apostolescui, $\boldsymbol{E}$. aff. $\boldsymbol{E}$. vitiosa, and in a minor proportion by $L$. lanceolata and $C$. toarcensis; meanwhile the Semicelatum Subzone ostracode assemblages are dominated by $K$. sermoisensis, $\boldsymbol{L}$. Lanceolata, and $C$. toarcensis.

As for the magnetostratigraphy, the data presented here are the most complete record of reversals of the Earth's magnetic field for the Pliensbachian-Toarcian boundary. A new Magnetic Polarity Time Scale (MPTS) is proposed in this paper, which includes recent magnetostratigraphic studies of the Toarcian interval carried out in the Iberian Range and the new data presented in this study for the PliensbachianToarcian boundary. Our new MPTS is consistent with previous studies, but is more complete (including magnetozones that were absent in previous papers), and the age is better controlled.

A good record of the onset of the positive $\delta^{13} \mathrm{C}$ excursion reported in many European sections has been obtained in the Almonacid de la Cuba section. The data presented in this work show a good latest Pliensbachian-earliest Toarcian $\delta^{18} O_{\text {bel-based pale- }}$ otemperature curve. Average paleotemperatures measured in the latest Pliensbachian Spinatum Biochron are of about $12.5^{\circ} \mathrm{C}$. A marked increase of the seawater temperature started during the earliest Toarcian. In the Tenuicostatum Biochron average temperatures of $16.7^{\circ} \mathrm{C}$ in the Almonacid de la Cuba section were recorded.

The ${ }^{87} \mathrm{Sr} /{ }^{86} \mathrm{Sr}$ values obtained in the Almonacid de la Cuba section filly agree with the previously published data. The Upper Pliensbachian ${ }^{87} \mathrm{Sr} /{ }^{86} \mathrm{Sr}$ values generally decrease during the Hawskerense Biochron, reaching a first minimum value in the late portion of this time interval, and slightly increase in the latest portion of this Biochron. Minimum values are recorded at the base of the Toarcian, as predicted by the LOWESS calibration curves, and ${ }^{87} \mathrm{Sr} /{ }^{86} \mathrm{Sr}$ slowly increases along the Tenuicostatum Zone.

\section{ACKNOWLEDGMENTS}

We are grateful to Drs. B.L. Nikitenko and V.A. Zakharov for comments that helped to improve the manuscript. This research work was financed by projects 
CGL2005-01765/BTE，CGL2005-00211/BTE， and CGL2008-03112/BTE of the Spanish Ministerio de Ciencia e Innovación and UCM-BSCH.910431. We acknowledge F. Heller for his valuable advice and the group of paleomagnetism of the Institut für Geophysik (ETH Zürich) for the use of the paleomagnetic laboratory. We are indebted to Sergi Elmi for his interesting suggestions and comments and because he supported our proposal of Almonacid de la Cuba as a reference section for the Pliensbachian-Toarcian boundary.

Reviewers B.L. Nikitenko and V.A. Zakharov

\section{REFERENCES}

1. Y. Alméras and P. Fauré, "Les Brachiopodes liasiques des Pyrénées. Paléontologie, Biostratigraphie, Paléobiogéographie et Paléoenvironnements," Strata 36, 1395 (2000).

2. T. F. Anderson and M. A. Arthur, "Stable Isotopes of Oxygen and Carbon and Their Application to Dedimentologic and Paleoenvironmental Problems," SEPM Short Course 10, 1-151 (1983).

3. C. Arias, "The Pliensbachian-Toarcian Boundary Ostracod Biostratigraphy in the Cordillera Iberica, Northeastern Spain," N. Jahrb. Geol. Paläontol. Abh. 216, 153-193 (2000).

4. C. Arias, "Extinction Pattern of Marine Ostracoda Across the Pliensbachian-Toarcian Boundary in the Cordillera Ibérica, NE Spain: Causes and consequences," Geobios 42, 1-16 (2009).

5. T. R. Bailey, Y. Rosenthal, J. M. McArthur, B. van de Schootbrugge, and M. F. Thirlwall, "Paleoceanographic Changes of the Late Pliensbachian Early Toarcian Interval: A Possible Link to the Genesis of an Oceanic Anoxic Event," Earth Planet. Sci. Lett. 212, $307-320$ (2003).

6. M. Bécaud, "Les Hildoceratidae (Ammonitina) du Toarcien de la bordure sud et sudest du Massif Armoricain (France)," Doc. Lab. Géol. Lyon 162, 1-245 (2006).

7. I. Boomer, "Lower Jurassic Ostracoda from Ilmister, Somerset, England," J. Micropaleontol. 9 (2), 205218 (1992)

8. J. C. Braga, "Ammonites del Domerense de la Zona Subbética (Cordilleras Béticas, S. de España)," Tesis Doctoral (Universidad de Granada, 1983), pp. 1-410.

9. J. C. Braga, M. J. Comas-Rengifo, A. Goy, and P. Rivas, "Comparaciones faunísticas y correlaciones en el Pliensbachiense de la Zona Subbética y Cordillera Ibérica," Bol. R. Soc. Esp. Hist. Nat. (Sec. Geol.) 80, 221-244 (1982).

10. J. C. Braga, M. J. Comas-Rengifo, A. Goy, and P. Rivas, "The Pliensbachian of Spain. Ammonite Succesion, Boundaries and Correlations," in I International Symposium on Jurassic Stratigraphy (Geological Survey of Denmark, Copenhagen, 1984), pp. 160-176.

11. M. J. Comas-Rengifo, "E1 Pliensbachiense de la Cordillera Ibérica," Tesis Doctoral (Facultad de Ciencias Geológicas, UCM, 1982; Colección Tesis Doctorales, UCM, 1985), pp. 1-591.
12. M. J. Comas-Rengifo, F. García Joral, and A. Goy, "Spiriferinida (Brachiopoda) del Jurásico Inferior del NE y $\mathrm{N}$ de España: distribución y extinción durante el evento anóxico oceánico del Toarciense inferior," Bol. R. Soc. Esp. Hist. Nat. (Sec. Geol.) 101, 147-157 (2006).

13. M. J. Comas-Rengifo and A. Goy, "E1 Pliensbachiense-Toarciense en la Rambla del Salto (Sierra Palomera, Teruel)" (Dpto. Paleontología, Facultad de CC. Geológicas, Universidad Complutense de Madrid, 1978), pp. IV.1-IV.11.

14. M. J. Comas-Rengifo, J. J. Gómez, A. Goy, C. Herrero, N. Perilli, and A. Rodrigo, "El Jurásico Inferior en la sección de Almonacid de la Cuba (Sector central de la Cordillera Ibérica, Zaragoza, España)," Cuad. Geol. Ibér. 25, 27-57 (1999).

15. M. J. Comas-Rengifo, A. Goy, and N. Perilli, "Ammonite and Calcareous Nannof ossil of the Expanded and Continuous Section of Almonacid de la Cuba II (Cordillera Ibérica, Spain): A Possible Pliensbachian/Toarcian Boundary Stratotype," in VI International Symposium on the Jurassic System (Mondello, Sicilia Abstracts and Program, 2002), pp. 37-38.

16. P. C. de Graciansky, T. Jacquin, and S.P. Hesselbo, "The Ligurian Cycle: An Overview of Lower Jurassic 2nd-Order Transgressive/Regressive Facies Cycles in Western Europe," SEPM Spec. Publ. 60, 467-479 (1998).

17. W. T. Dean, D. T. Donovan, and M. K. Howarth, "The Liassic Ammonite Zones and Subzones of the Northwest European Province," Bull. Brit. Mus. (Nat. Hist.), Geol. Ser. 4, 435-505 (1961).

18. J. L. Dommergues, C. Meister, and R. Mouterde, "Pliensbachien, in E. Cariou and P. Hantzpergue (Coord.). Biostratigraphie du Jurassique ouesteuropéen et méditerranéen: zonations parallèles et distribution des invertébrés et microfossiles," Bull. Centre Rech. Explor. Prod. Elf Aquitaine 17, 15-23 (1997).

19. L. V. Duarte, "Clay Minerals and Geochemical Evolution in the Toarcian-Lower Aalenian of the Lusitanian Basin (Portugal)," Cuad. Geol. Ibér. 24, 69-98 (1998).

20. L. V. Duarte, "Sequence Stratigraphy and Depositional Setting of the Pliensbachian and Toarcian Marly Limestones in the Lusitanian Basin, Portugal," Volumina Jurassica 4, 157-158 (2006).

21. S. Elmi, "Toarcian GSSP Candidate: The Peniche Section," in Carboniferous and Jurassic Carbonate Platforms of Iberia (Imprensa Coimbra Lda, Coimbra, 2004), pp. 64-67.

22. S. Elmi, "Pliensbachian-Toarcian Boundary: the Proposed GSSP of Peniche (Portugal)," Volumina Jurassica 4, 5-16 (2006).

23. S. Elmi, F. Atrops, and C. Mangold, "Les zones d'ammonites du Domerien-Callovien. de l'Algérie Occidentale. $1^{\text {ere }}$ partie: Domerien-Toarcien," Doc. Lab. Géol. Lyon 61, 3-83 (1974).

24. S. Elmi, A. Goy, R. Mouterde, P. Rivas, and R. B. Rocha, "Correlaciones bioestratigráficas en el Toarciense de la Península Ibérica," Cuad. Geol. Ibér. 13, 265-277(1989).

25. S. Elmi, J. Gabilly, R. Mouterde, L. Rulleau, and R. B. Rocha, "L'étage Toarcien de l'Europe et de la 
Téthys: divisions et corrélations," Geobios. Mém. Spéc. 17, 149-159 (1994).

26. S. Elmi, R. Mouterde, R. B. Rocha, and L. V. Duarte, "La limite Pliensbachien-Toarcien au Portugal; intérêt de la coupe de Peniche," Aalenews 6, 33-35 (1996).

27. S. Elmi, L. Rulleau, J. Gabilly, and R. Mouterde, "Toarcian, in E. Cariou and P. Hantzpergue (Coord.). Biostratigraphie du Jurassique ouest-européen et méditerranén: zonations parallèles et distribution des invertébrés et microfossiles," Bull. Centre Rech. Explor. Prod. Elf Aquitaine 17, 25-36 (1997).

28. S. Elmi, A. Marok, A. Sebane, and Y. Alméras, "Importance of the Mellata Section (Traras Mountains, NW Algeria) for the Correlations of the Pliensbachian/Toarcian Boundary," Volumina Jurassica 4, 158-160 (2006).

29. J. Exton and F. M. Gradstein, "Early Jurassic Stratigraphy and Micropaleontology of the Grand Banks and Portugal," in Jurassic and Cretaceous Biochronolozy and Biogeography of North America, Ed by G. E. G. Westerman, 1984, pp. 13-28.

30. P. Fauré, Y. Alméras, N. Sekatni, and F. Zargouni, "Le Pliensbachien de Jebel Zaghouan (Tunisie). Nouvelles données fauniques. Implications biostratigraphiques et paléobiogéographiques," Geodiversitas 29, 473-506 (2007).

31. R.A. Fisher, "Dispersion on a Sphere," Proc. Roy. Soc. London 217, 295-305 (1953).

32. B. Galbrun, B. J. Gabilly, and L. Raspins, "Magnetostratigraphy of the Toarcian Stratotype Sections at Thouars and Airvault (Des-Serves, France)," Earth Planet. Sci. Lett. 87, 453-462(1988).

33. B. Galbrun, F. Baudin, E. Fourcade, and P. Rivas, "Magnetostratigraphy of the Toarcian Ammonitico Rosso Limestone at Iznalloz, Spain," Geophys. Res. Lett. 17, 2441-2444 (1990).

34. M. E. Gahr, "Palökologie des Makrobenthos aus dem Unter-Toarc SW-Europas," Beringeria 31, 3-204 (2002).

35. F. García Joral and A. Goy, "Características de la fauna de braquiópodos del Toarciense Superior en el Sector Central de la Cordillera Ibérica (Noreste de España)," Est. Geol. 40, 55-60 (1984).

36. F. García Joral and A. Goy, "Stratigraphic Distribution of Toarcian Brachiopods from the Iberian Range (Spain) and Its Relation to Depositional Sequences". GeoResearch Forum 6, 381-386 (2000).

37. P. Gianolla and T. Jacquin, "Triassic Sequences Stratigraphic Framework of Western European Basins," SEPM Spec. Publ. 60, 643-650 (1998).

38. J. J. Gómez, "Sedimentología y paleogeografía del Jurásico en la hoja geológica n ${ }^{\circ} 40(7-5)$ de Daroca del Mapa Geológico de España a escala de 1 : 200.000" (Instituto Tecnológico y Geominero de España, 1991), pp. $31-82$.

39. J. J. Gómez and A. Goy, "Sequential Analysis of the Toarcian in the Northern and Central-Eastern Part of the Iberian Subplate, Spain," GeoResearch Forum 6, 301-309 (2000).

40. J. J. Gómez and A. Goy, "Late Triassic and Early Jurassic Palaeogeographic Evolution and Depositional Cycles of the Western Tethys Iberian Platform System
(Eastern Spain)," Palaeogeogr. Palaeoclimat. Palaeoecol. 222, 77-94 (2005).

41. J. J. Gómez, A. Goy, and M. L. Canales, "Seawater Temperature and Carbon Isotope Variations in Belemnites Linked to Mass Extinction during the Toarcian (Early Jurassic) in Central and Northern Spain. Comparison with Other European Sections," Palaeogeogr. Palaeoclimat. Palaeoecol. 258, 28-58 (2008).

42. W. A. Gordon, "Biogeography of Jurassic Foraminifera," Geol. Soc. Am. Bull. 81, 1689-1704 (1970).

43. A. Goy, M. J. Comas-Rengifo, C. Arias, F. García Joral, J. J. Gómez, C. Herrero, G. Martinez, and A. Rodrigo, "El Tránsito Pliensbachiense/Toarciense en el sector central de la RamaAragonesa de la Cordillera Ibérica (España)," Cah. 1'Instit. Cathol. Lyon 10, 159-179 (1997).

44. A. Goy, M. J. Comas-Rengifo, C. Arias, J. J. Gómez, A. González, C. Herrero, A. Palencia, N. Perilli, and A. Rodrigo, "The Pliensbachian/Toarcian boundary in the Almonacid de la Cuba section (Iberian Range, Spain)," Volumina Jurassica 6, 164-165 (2006).

45. A. Goy, A. Jiménez, G. Martínez, and P. Rivas, "Difficulties in Correlating the Toarcian Ammonite Succession of the Iberian and Betics Cordilleras," in 2nd International Symposium on Jurassic Stratigraphy (Lisboa, 1988), pp. 155-178.

46. A. Goy and G. Martínez, "Biozonación del Toarciense en el área de La Almunia de Doña Godina-Ricla (Sector Central de la Cordillera Ibérica)," Cuad. Geol. Ibér. 14, 11-53 (1990).

47. J. Guex, "Aperçu biostratigraphique sur le Toarcien inférieur du Moyen-Atlas marocain et discussion sur la zonation de ce sous-étage dans les séries méditerranéennes," Eclogae geol. Helv. 66, 493-523 (1973).

48. B. L. Haq, J. Hardenbol, and P. Vail, "Mesozoic and Cenozoic Chronostratigraphy and Eustatic Cycles," SEPM Spec. Publ. 42, 71-108 (1988).

49. C. Herrero, "Sucesión de asociaciones de foraminíferos en el tránsito Pliensbachiense-Toarciense en Almonacid de la Cuba (Zaragoza, España)," Rev. Esp. Micropal. 38, 339-354 (2006).

50. C. Herrero, "Foraminiferal Events in the Pliensbachian-Toarcian Transition at Almonacid de la Cuba (Zaragoza, Spain), the Complementary Reference Section of the Proposed Toarcian GSSP," N. Jb. Geol. Paläont. Abh. 250, 233-255 (2008).

51. S. P. Hesselbo and H. C. Jenkyns, "A Comparison of the Hettangian to Bajocian Successions of Dorset and Yorkshire," in Field Geology of the British Jurassic (Geological Society of London, 1995), pp. 105-150.

52. S. P. Hesselbo, H. C. Jenkyns, L. V. Duarte, and L. C. V. Oliveira, "Carbon-Isotope Record of the Early Jurassic (Toarcian) Oceanic Anoxic Event from Fossil Wood and Marine Carbonate (Lusitanian Basin, Portugal)," Earth Planet. Sci. Lett. 253, 455-470 (2007).

53. A. V. Hillebrandt, "Liassic Ammonite Zones of South America and Correlations with Other Provinces. Description of New Genera and Species of Ammonites," in Bioestratigrafia de los Sistemas Regionales del Jurásico y Cretácico en América del Sur (Volkheimer W. Ed. Mendoza, Argentinien, 1987), pp. 111-157. 
54. A. V. Hillebrandt and R. Schmidt-Effing, "Ammoniten aus dem Toarcium (Jura) von Chile (Sudamerika)," Zitteliana 6, 3-64 (1981).

55. F. Horner and F. Heller, "Lower Jurassic Magnetostratigraphy at the Breggia Gorge (Ticino, Switzerland) and Alpe Turati (Como, Italy)," Geophys. J. R. Astron. Soc. 73, 705-718 (1983).

56. M.K. Howarth, "AMonograph of the Ammonite of the Liassic Family Amaltheidae in Britain," Palaeontol. Soc. London, 111, 1-26 (1957); Part 2, 112, 27-53 (1958).

57. M. K. Howarth, "The Stratigraphy and Ammonite Fauna of the Upper Liassic Grey Shales of the Yorkshire Coast," Bull. Brit. Mus. (Nat. Hist.), Geol. Ser. 24, 237-277 (1973).

58. M. K. Howarth, "The Stratigraphy and Ammonite Fauna of the Upper Lias of Northamptonshire," Bull. Brit. Mus. (Nat. Hist.), Geol. Ser. 29, 235-288 (1978).

59. M. K. Howarth, "The Ammonitic Family Hildoceratidae in the Lower Jurassic of Britain," Monogr. Palaeont. Soc. London 145, 1-106 (1992).

60. M. P. Iglesia-Llanos and A. C. Riccardi, "The Neuquén Composite Section: Magnetostratigraphy and Biostratigraphy of the Marine Lower Jurassic from the Neuquén Basin (Argentina)," Earth Planet. Sci. Lett. 181, 443-457 (2000).

61. H. C. Jenkyns, "Evidence for Rapid Climate Change in the Mesozoic-Palaeogene Greenhouse World," Phil. T. Roy. Soc. 361, 1885-1916 (2003).

62. H. C. Jenkyns and C. J. Clayton, "Lower Jurassic Epicontinental Carbonates and Mudstones from England and Wales: Chemostratigraphic Signals and the Early Toarcian Anoxic Event," Sedimentology 44, 687-706 (1997).

63. E. D. Kalacheva, "Toarcian," in The Jurassic Ammonite Zones of the Soviet Union (Geological Society of America, Special Paper, 1988), pp. 14-18.

64. N. Lachkar, J. L. Dommergues, Ch. Meister, J. Lang, and E. H. Chellai, "Apport des ammonites au cadre biostratigraphique et chronostratigraphique du HautAtlas de Rich au cours du Lias (Maroc)," Africa Geosci. Rew. 14, 95-105 (2007).

65. W. Lowrie, "Identification of Ferromagnetic Minerals in a Rock by Coercivity and Unblocking Temperature Properties," Geophys. Res. Lett. 17, 159-162 (1990).

66. F. Macchioni, "Myths and Legends in the Correlation between the Boreal and Tethyan Realms. Implications on the Dating of the Early Toarcian Mass Extinctions and the Oceanic Anoxic Event," Geobios, Mém. Spéc. 35, 150-164 (2002).

67. F. Macchioni and F. Cecca, "Biodiversity and Biogeography of Middle-Late Liassic Ammonoids: Implications for the Early Toarcian Mass Extinction," Geobios, Mérn. Spéc. 35, 165-175 (2002).

68. F. Macchioni and C. Meister, "Ammonite Biostratigraphy of Some Mediterranean Sections, Vol. 2: The Succession of the Gola del F. Burano (Umbria-Machigiano Basin, Apennine), a Reference Section for Tethyan Domain," Rev. Paléobiol. Genéve 22, 363420 (2003).

69. J. M. McArthur, D. T. Donovan, M. F. Thirlwall, B. W. Fouke, and D. Mattey, "Strontium Isotope Pro- file of the Early Toarcian (Jurassic) Oceanic Anoxic Event, the Duration of Ammonite Biozones, and Belemnite Palaeotemperatures," Earth Planet. Sci. Lett. 179, 269-285 (2000).

70. J. M. McArthur, R. J. Howarth, and T. R. Bailey, "Strontium Isotope Stratigraphy: LOWESS Version 3: Best Fit to the Marine Sr Isotope Curve for -509 Ma and Accompanying Look-Up Table for Deriving Numerical Age," J. Geol. 109 (2), 155-170 (2001).

71. J. M. McArthur and R. J. Howarth, "Strontium Isotope Stratigraphy," in A Geological Time Scale 2004 (Cambridge Univ. Press, Cambridge, 2004), pp. 96-105.

72. P. L. McFadden and D. L. Jones, "The Fold Test in Palaeomagnetism," Geophys. J. R. Astron. Soc. 67, 53-58 (1981).

73. P. L. McFadden and M. W. McElhinny, "Classification of the Reversal Test in Palaeomagnetism," Geophys. Intern. J. 103, 725-729 (1990).

74. P. L. McFadden and A. Reid, "Analysis of Paleomagnetic Inclination Data," Geophys. J. R. Astron. Soc. 69, 307-319 (1982).

75. C. Meister, P. Schirolli, and J. L. Dommergues, "Sinemurian to Lowermost Toarcian of the Brescian Alps (Southern Alps, Italy): Biostratigraphical Framework and Correlations," Volumina Jurassica 4, 184-185 (2006).

76. O. Michelsen, "Lower Jurassic Biostratigraphy and Ostracoda of the Danish Embayment," Dan. Geol. Unders. 104 (2), 1-289 (1975).

77. M. G. Moreau, H. Bucher, A. M. Bodegart, and J. Guex, "Pliensbachian Magnetostratigraphy: New Data from Paris Basin (France)," Earth Planet. Sci. Lett. 203, 755-767 (2002).

78. R. Mouterde, "Le Lias de Peniche," Corn. Serv. Geol. Port. 36, 87-115 (1955).

79. R. Mouterde, "Le Lias du Portugal. Vue d'ensemble et divisions en zones," Corn. Serv. Geol. Port. 52, 209226 (1967).

80. B. L. Nikitenko, "The Early Jurassic to Aalenian Paleobiogeography of the Arctic Realm: Implication of Microbenthos (Foraminifers and Ostracodes)," Stratigr. Geol. Correlation 16, 59-80 (2008).

81. J. G. Ogg, "Magnetic Polarity Time Scale of the Phanerozoic," in Global Physics. A Handbook of Physical Constants (AGU Reference Shelf, 1995), pp. 240270.

82. J. G. Ogg, "The Jurassic Period" in A Geologic Time Scale 2004 (Cambridge Univ. Press, Cambridge, 2004), pp. 307-343.

83. M. L. Osete, J. J. Villalaín, C. Osete, and P. R. Gialanella, "Evolución de Iberia durante el Jurásico a partir de datos paleomagnéticos," Geotemas 1, 117-119 (2000).

84. M. L. Osete, P. R. Gialanella, J. J. Gómez, J. J. Villalaín, A. Goy, and F. Heller, "Magnetostratigraphy of Early-Middle Toarcian Expanded Sections from the Iberian Range (Central Spain)," Earth Planet. Sci. Lett. 259, 319-332 (2007).

85. K. Page, "The Lower Jurassic of Europe: Its Subdivision and Correlation," in The Jurassic of Denmark and Greenland (Geological Survey Denmark and Greenland Bulletin, 2003), pp. 23-59. 
86. A. C. Riccardi, "The Marine Jurassic of Argentina: A Biostratigraphic Framework," Episodes 31, 326-365 (2008).

87. W. Riegraf, "Microfauna, Biostratigraphie und Fazies im Unteren Toarcium Sudwestdeutschlands und Vergleiche mit benachbarten Gebieten," Tubinger Micropalaontology 3, 1-232 (1985).

88. H. J. Röhl, A. Schmid-Röhl, W. Oschmann, A. Frimmel, and L. Schwark, "The Posidonia Shale (Lower Toarcian) of SW Germany: an Oxygen-Depleted Ecosystem Controlled by Sea Level and Palaeoclimate," Palaeogeogr. Palaeoclimat. Palaeoecol. 165, 27-52 (2001).

89. I. Rosales, S. Robles, and S. Quesada, "Registro de la composición isotópica del Jurásico inferior de la Cuenca Vascocantábrica: metodología analitica y relación con los depósitos orgánicos," Geotemas 3, 61-64 (2001).

90. I. Rosales, S. Quesada, and S. Robles, "Paleotemperature Variations of Early Jurassic Seawater Recorded in Geochemical Trends of Belemnites from the BasqueCantabrian Basin, Northern Spain," Palaeogeogr. Palaeoclimat. Palaeoecol. 203, 253-275 (2004).

91. V. Ruiz, A. Lendínez, and V. Gabaldón, Geological Map of Spain at the Scale of 1: 50000. Sheet 440, Belchite (ITGE, Madrid, 1986).

92. G. Sælen, P. Doyle, and M. R. Talbot, "Stable-Isotope Analyses of Belemnite Rostra from the Whitby Mudstone Fm. England: Surface Water Conditions during Deposition of a Marine Black Shale," Palaios 11, 97117 (1996).
93. A. Schmid-Röhl, H. J. Röhl, W. Oschmann, A. Frimmel, and L. Schwark, "Palaeoenvironmental Reconstruction of Lower Toarcian Epicontinental Black Shales (Posidonia Shale, SW Germany): Global Versus Regional Control," Geobios 35, 13-20 (2002).

94. S. Schouten, H. M. E. van Kaam-Peters, W. I. C. Rijpstra, M. Schoell, and J. S. Sinninghe Damste, "Effects of an Oceanic Anoxic Event on the Stable Carbon Isotopic Composition of Early Toarcian Carbon," Amer. J. Sci. 300, 1-22 (2000).

95. L. Sequeiros, I. Cólera, R. Valenzuela, and L. Sánchez, "Bioestratigrafía del Jurásico (Lias y Dogger) en el sector Belchite-Almonacid de la Cuba (prov. de Zaragoza, Cordillera Ibérica)," Estud. Geol. 34, 293-298 (1978).

96. F. Tremolada, B. van de Schootbrugge, and E. Erba, "Early Jurassic Schizosphaerellid Crisis in Cantabria, Spain: Implications for Calcification Rates and Phytoplankton Evolution Across the Toarcian Oceanic Anoxic Event," Paleoceanography 20, A201. doi: 10.1029/2004PA001120 (2005).

97. E. K. Wright, "Stratification and Paleocirculation of the Late Cretaceous Western Interior Seaway of North America," Geol. Soc. Am. Bull. 99, 480-490 (1987).

98. V. A. Zakharov, Yu. I. Bogomolov, V. I. Il'ina, et al., "Boreal Zonal Standard and Biostratigraphy of the Mesozoic of Siberia," Geol. Geofiz. 38, 927-956 (1997).

99. V. A. Zakharov, B. N. Shurygin, V. I. Il'ina, and B. L. Nikitenko, "Pliensbachian-Toarcian Biotic Turnover in North Siberia and the Arctic Region," Stratigraph. Geol. Correlation 14, 399-417 (2006). 